Ambiances

anbiances Environnement sensible, architecture et espace urbain

$3 \mid 2017$

Animer l'espace public ? Entre programmation urbaine et activation citoyenne

\title{
Walking and standing in Athinas Street: Encountering pedestrian life in Athens' historical centre
}

Postures de la marche dans la rue Athinas : à la rencontre de la vie piétonne au centre historique d'Athènes

Dimitra Kanellopoulou

\section{OpenEdition}

Journals

Electronic version

URL: https://journals.openedition.org/ambiances/1047

DOI: 10.4000/ambiances. 1047

ISSN: 2266-839X

Publisher:

Direction Générale des Patrimoines - DAPA - MCC, UMR 1563 - Ambiances Architectures Urbanités $(\mathrm{AAU})$

Electronic reference

Dimitra Kanellopoulou, "Walking and standing in Athinas Street: Encountering pedestrian life in Athens' historical centre", Ambiances [Online], 3 | 2017, Online since 10 December 2017, connection on 21 September 2021. URL: http://journals.openedition.org/ambiances/1047 ; DOI: https://doi.org/ 10.4000/ambiances. 1047

This text was automatically generated on 21 September 2021

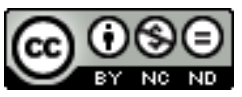

Ambiances is licensed under a Creative Commons Attribution-NonCommercial-NoDerivatives 4.0 International License. 


\title{
Walking and standing in Athinas Street: Encountering pedestrian life in Athens' historical centre
}

\author{
Postures de la marche dans la rue Athinas : à la rencontre de la vie piétonne au \\ centre historique d'Athènes
}

Dimitra Kanellopoulou

\section{Introduction}

1 By the end of 1970s, the public spaces of Athens resembled numerous construction sites. Neighbourhood streets transformed into playgrounds, central avenues redesigned to host tram lines, and public squares refurbished with urban furniture, together created a brand new image for the city's historical centre. After the 1990s, state authorities extensively promoted widespread pedestrianisation, whilst understanding of the practice of walking per se, or the factors that stimulate social interaction in public space, are issues that have been losing prominence within public debate (Kanellopoulou, 2015, p. 43). Since 2000, in a context of aggravated economic crisis, the Ministry's investment and private sponsorships in showcase pedestrianisation projects have mostly targeted central zones with high symbolic and economic value (Chatzimichalis, 2011). Animating street life is seen as a priority issue in discussions and studies of public space planning. At the same time, sophisticated green promenades, restaurants, and cafes proliferate in central streets, and privately funded projects prioritise leisure activities or glamorous landscape designs as key factors in the 'success' of public space (Siatista, 2011). However, the extensive use of pedestrianisation by Greek public space planning authorities does not necessarily link the social role of walking with the 'success' of public spaces. Furthermore, pedestrianisation initiatives fail to respond to the escalation of real estate prices (due to costly projects) and risk the homogenisation of the commercial, physical and social environment of the places concerned. Considering pedestrianisation as a remedy to improve public space risks marginalising the plural character of walking 
which, more than transport or leisure activity, remains a social practice intrinsically linked to the life, image and function of Athenian public space.

\section{Athinas Street: thoughts on a popular place}

Despite pressure from neighbouring areas that are highly touristic, Athinas Street remains a popular place where visitors, inhabitants, migrants and traders throng the sidewalks (Filippidis, 2001). In 2001 the municipality expressed its intention to rehabilitate the street, aiming to achieve an aesthetic and functional upgrade through a project of partial pedestrianisation (Chlepa, 2008, p. 113). Beyond its centrality in geographical terms, Athinas Street presents some unique characteristics that make it stand out within the network of public spaces in the city centre. Although it is not pedestrianised, the street succeeds in hosting intense daily life nourished by a heterogeneous public. Backpackers visiting low-budget hostels, pensioners strolling around the central fish market, artists searching for materials in the numerous wholesale stores, chefs negotiating on the price of delicacies in traditional butchers' shops, proprietors of hardware and kitchen stores, street vendors, all meet and share the busy pavements of the historic avenue. Hardware stores, barbers' shops, embroidery shops and stores selling cooking utensils are mixed together with spice vendors, gardening stores, grocers and pet shops, weaving a noisy, colourful landscape for walkers to see (Figure 1).

Figure 1: Image of the pavement in Athinas Street

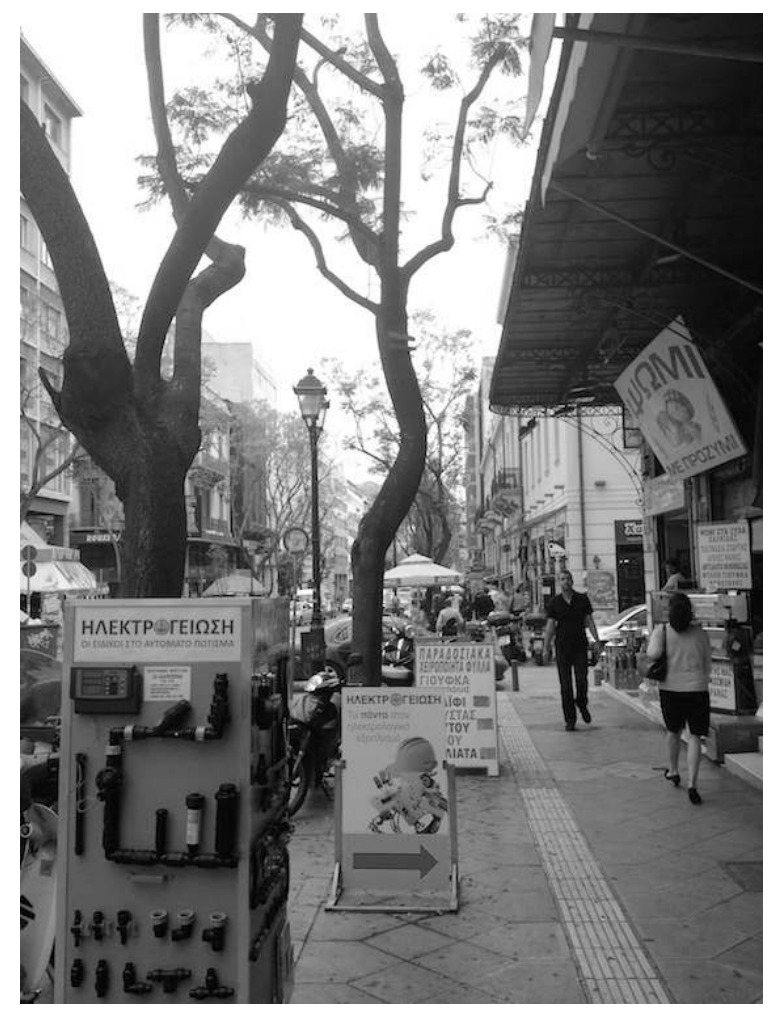

SOURCE AND COPYRIGHT: @ DIMITRA KANELLOPOULOU.

3 At a time when several public spaces are facing radical transformation due to the removal of local commerce, excessive tourist activity and costly pedestrianisation work, Athinas 
Street has preserved its vivid street life and local character over the years, remaining a popular place in the centre of the capital.

\section{Pedestrianisation: a 'remedy' for the decline of city centres}

Apart from their high costs, pedestrianisation projects within the historical centre risk the removal of small commercial enterprises, an increase in land values and a massive expansion in cafes, restaurants and franchises as highly profitable activities linked to the growth of tourism industry. Pedestrianisation is not proven to be either a necessary or a sufficient condition to promote social interaction, as it does not always ensure diversity of usage and users, and to date it has been linked - in the case of the Greek capital - to rigid (in terms of operations and regulation) top-down procedures behind closed doors. Particularly in the context of poor public finances and huge expenses needed for public works, seeking ways of animating streets and encouraging social interaction where it already exists is, I argue, crucial for urban planning, where the scope for action needs to be enlarged in order to foster the social role of public space.

5 I will tend to examine the factors involved in enlivening Athinas Street, a space which is not yet exposed to radical transformations of its image and function, and explore the ways in which the interrelation of factors such as the morphology of the urban fabric, local identity, unintentional and intentional practices, can create a vivid urban space. The study aims to demonstrate that liveable public spaces depend not so much on a wellhoned top-down planning procedure, but can arise through a subtle equilibrium of designed urban space and unplanned routine practices that give public spaces continuity in collective memory, meaning, and a feeling of familiarity. Understanding what fosters street life can, I argue, further nourish planners' vocabulary and priorities. Commonly promoted public policies in Athens support the transformation of central streets into promenading axes in order to revive public life as a response to a city centre that has been wounded by the crisis and the economic development of the suburbs. In the face of this crisis in public spaces in the city centre, a counter-paradigm for rejuvenation needs to be drawn up. Pedestrianisation cannot be characterised as a 'failed' urban planning tool in general. Drawing on the example of Athinas Street, I will however argue that urban planners and public debate need to question the dominance of such a tool within public space planning strategies in the future.

\section{Aims and hypothesis of the study}

6 By examining popular ordinary places in cities, and understanding how these places accommodate a heterogeneous array of people and activities, planners can proceed to the creation of more welcoming and thus more democratic public spaces. The liveability of public space can thrive in routine street life, in a variety of neighbouring and interdepent activities.

My first hypothesis is that, taken together, all the most insignificant activities in Athinas Street that are not intented to animate it can play a significant role in enlivening the social life, ambiance and identity of public space. Contrary to the design of promenade streets, pedestrian tourist precincts or commercial avenues with extensive provision of 
franchise stores, pedestrian life in Athinas Street results from numerous open air microactivities that, without dominating the place, coexist with each other and contribute to the general ambiance ${ }^{1}$ (Thibaud, 2002, p. 196) of the street.

My second hypothesis is that animation of Athinas Street is not the intentional result of a planned environment, but the effect of the co-existence and interrelation of a variety of practices and behaviours of people using the sidewalks and being in public.

9 My third hypothesis is that street life also depends strongly on cultural aspects (life outside, negotiating on prices) habits (wandering) and local identity (commercial street, meeting point) of public space.

10 I will tend to examine these hypotheses through fieldwork investigation, tending to illustrate ways in which routine walkers' activities can be per se an animating factor for public space. The study presented here ${ }^{2}$ is the fruit of observations that I made in Athinas Street over two months in 2012, working in the field and following a predefined schedule of time slots on four days a week. Using this fieldwork, I aim to show that a non-designed pedestrian space that offer opportunities for use, frames of action and reasons to visit for a wider public can be a space that is greatly animated. Various forms of personal interaction (with others and with the built environment) are considered to be key elements in order for public space to be successful. Observing walking at close range, and trying to understand its temporal and spatial inscription, allows planners, humanities researchers and decision-makers to collaborate and deepen the debate on ways in which design and governance can deal with the role of walking practices in the creation of urban public spaces.

\section{Methodological approach}

Arriving at the field, several questions emerged as to how the survey could be organised. Two things had already become clear during the first investigatory walk: firstly, the movement of walking itself appears to be a complex practice composed of several smaller actions, such as watching, crossing, gazing or navigating within the crowd. Secondly, movement follows multiple stationary activities such as stopping temporarily, standing and sitting, which together foster pedestrian life $e^{3}$.

Wishing to adopt an urban geography perspective that uses ethnographic and phenomenological tools of analysis, I have decided to mobilise three survey methods in order to 'extract' information about pedestrian activity in the field:

Firstly, I observed walkers from a certain distance, without questioning their wishes, needs, or intentions; an approach that has been already highlighted by other scholars (Wunderlich, 2008). Scholars have already observed pedestrian movement and behaviour for various purposes (Mehta, 2009; Oosterman 1978). The ethical problem of observing people's behaviour without the latter being aware of it has already been pointed out by several manuals on anthropology and ethnography research methodologies (Ellen, 1984). I tried to respond to this problem by respecting the total anonymity of people who have been followed, by not using any videos or photographs. At the same time, there was the undeniable need to document their actions in real time and in a detailed way. Writing down the routes and the behaviour of pedestrians on paper was quickly proved to be inefficient. In the end, I chose to use a personal tie-clip audio recorder and comment 
directly on things that I was observing, while following the person at a distance of approximately seven metres.

14 The acts of following started from four specific points in the field: two on each pavement at the north end of the street, and two to the south end next to the metro exit (Figure 2).

Figure 2: Three zones of observation of pedestrian activity in Athinas Street

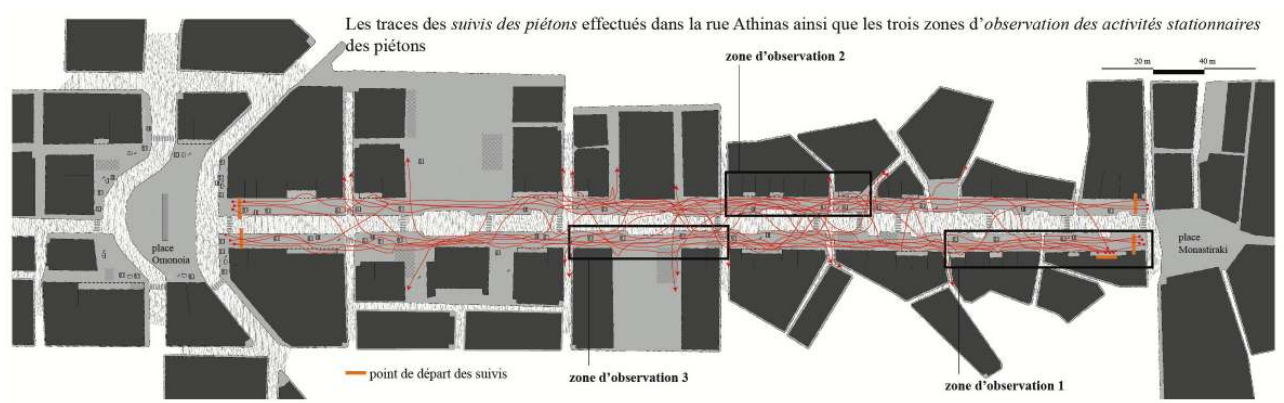

SOURCE AND COPYRIGHT: @ DIMITRA KANELLOPOULOU.

When people exited the street or entered a shop for a longer period of time, I stopped following them. After excluding several observations of really short duration that were of no interest for processing, twenty trajectories were finally analysed, presenting a satisfying sample with good representation of ages, forms of trajectories and actions undertaken.

Paths were first traced on paper and then transferred onto a digitalised map (Figure 3).

Figure 3: Observation sheets describing the route and the behaviour of each walker followed

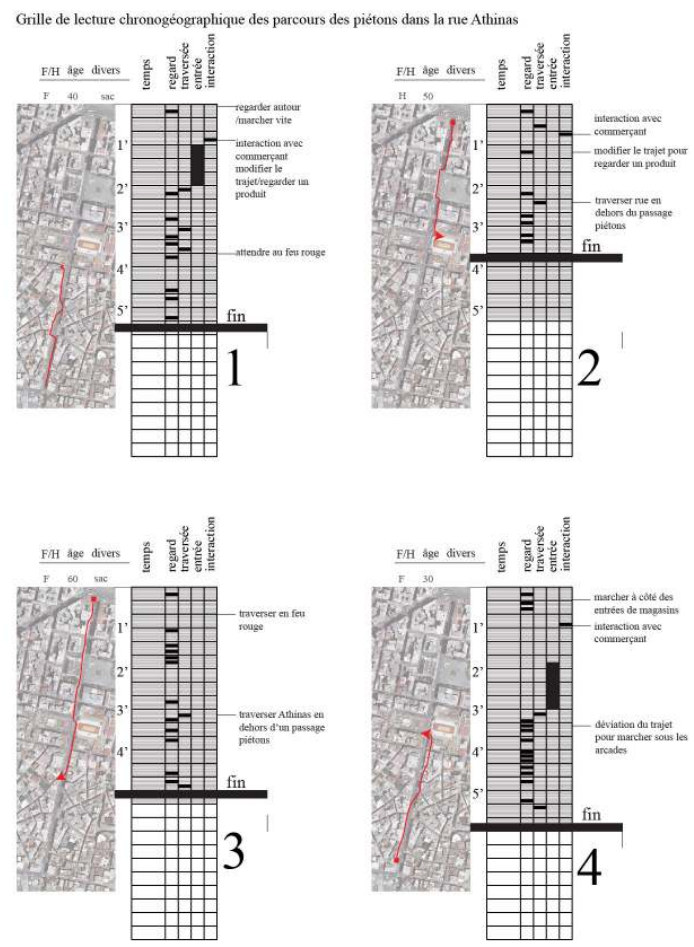

SOURCE AND COPYRIgHT: () DIMITRA KANELLOPOULOU. 
Walking trajectories observed were categorised in four major types of behaviour: watching a scene, interacting with others, crossing the street, and entering a shop.

Secondly, I observed in detail stationary activities within three frequented zones of the street (Figure 2). The observation of stationary activities within three distinctive zones of the street ${ }^{4}$ raised another methodological problem. It appeared to be difficult to register a wide range of actions just by standing still at a fixed point on the perimeter of a particular zone. In contrast, walking along the zone among pedestrians for determined time intervals (10 minutes) allowed me to capture a wider range of their actions. Observations revealed five behaviours that most frequently occurred when people were stationary: sitting, interacting with others, watching a shop window, standing alone or pursuing a less expected activity (Figure 4).

Figure 4: Example of observation sheets describing the spatial registration of different stationary activities on pavements

Cartes des activités stationnaires des piétons effectuées dans la zone 1 d'observation de la rue Athinas pendant des créneaux horaires choisis au cours des cinq jours de la semaine

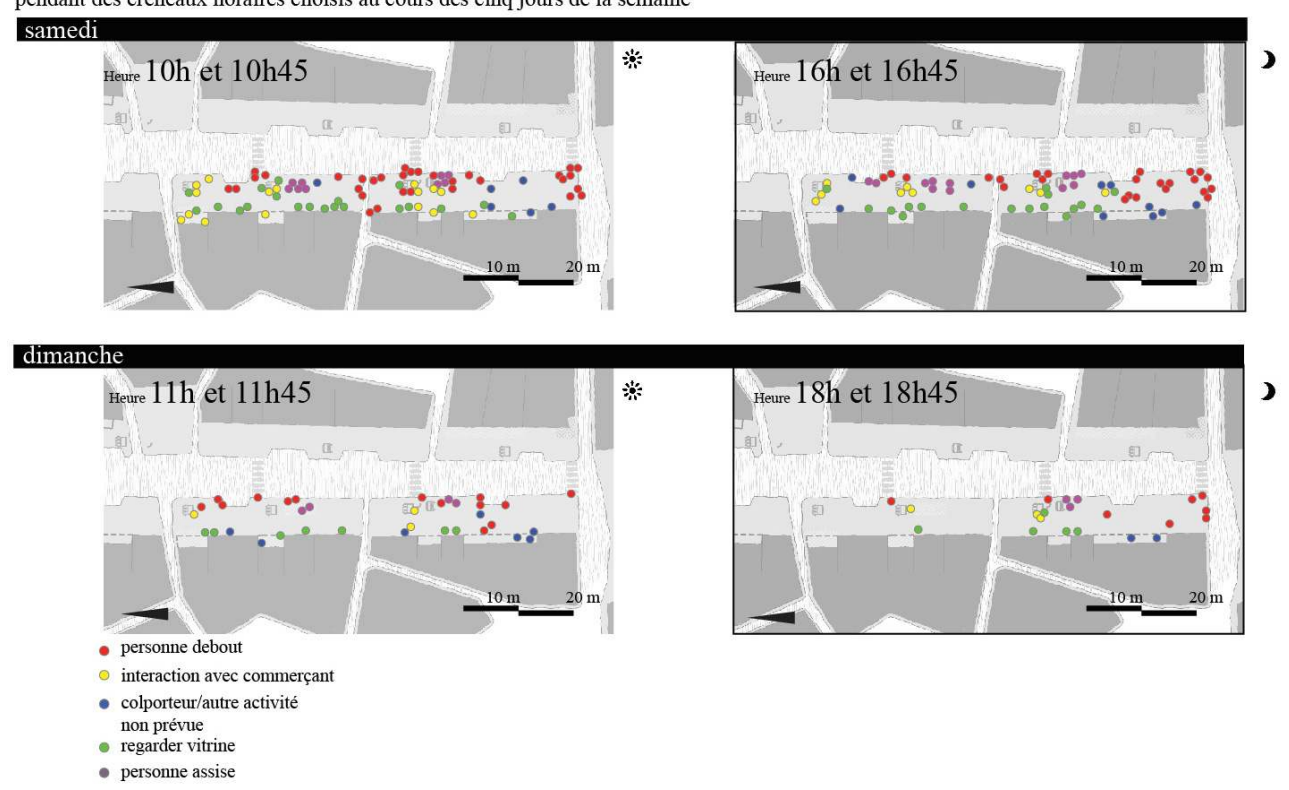

SOURCE AND COPYRIgHT: (C) DIMITRA KANELLOPOULOU.

By comparing - and transcribing on maps - the micro-uses of the pavements, I have tried to demonstrate that the liveliness of Athinas Street depends on a highly delicate choreography of walking that is woven by the acceleration and deceleration of steps, and the concentrations and dilutions of pedestrian encounters. Movement and pauses are nourished collaterally. The street's public life offers a spectacle that is not predetermined or linked directly with leisure. The pedestrians elevate the life of Athinas Street through their practice of constantly inventing their movements, appropriating their spaces, and encountering each other.

Thirdly, I have conducted semi-direct interviews with three traders at strategic points of the street (next to metro exits, crossroads or small squares). Some questions were basically used to frame the survey's objectives, but a free discussion was generally conducted with people that were interviewed. 


\section{Walking, shaping space}

21 Several scholars (Solnit, 2000; Joseph, 1984) have demonstrated how walking plays a crucial role in the shaping of our urban environments. More recently, walking has begun to be a prominent subject for research within the social sciences (Shortell \& Brown, 2014) and in transport policies (Amar \& Michaud, 2009). In the European city centres of the 1950s - which have now been conquered by the car - providing spaces for walking was synonymous with giving life back to deteriorating city centres (Levy, 1987). Early projects which appeared in the north were guided more by economic and social factors than by aesthetic motivations (Hass-Clau, 1993). Local authorities used pedestrianised zones to stimulate commercial activity, improve quality of life, and enhance sociability (CETUR, 1980). By the 1960s, human sciences, influenced by the work of Jürgen Habermas (Habermas, 1988), began to focus on the social meaning of collective spaces within the urban fabric, suggesting that the quality of physical spaces not only needs the presence of people 'somewhere' but is also dependent on the kind of social interaction that is produced in this 'somewhere' (Rapoport, 1970). Until the 1980s, researchers (Lofland, 1998) and practitioners across the Atlantic (Jacobs, 1961; Whyte, 1984) undertook what were at the time pioneering fieldwork surveys to try to understand how public life is organised within open space. More recently, geographers (Ghorra-Gobin, 2009) and planning professionals (Gehl, 2011) have observed pedestrians, arguing that life in public thrives not only thanks to design elements but is mostly a response to the variety of social profiles and activities that take place in urban spaces.

By the 1990s, sociologists began to criticise the planners' focus on design or economic issues, neglecting the sensory and social reasons for the construction of public spaces (Sennett, 1990). The soaring numbers of commercial malls, gentrified historical centres, and the spread of a transnational style in the built environment (Lawrence, 2006, p. 27) are seen as the signs of a progressively alienated, sterilised and privatised public space (Sorkin, 1992). Attracted by the perspective of radical geography, David Harvey (2008) argued that the social viability of public space depends chiefly on its capacity to embrace difference and freedom of expression. At the same time, Sharon Zukin (2010) forewarned that the city had lost its soul [the term used by Zukin]. Since the 1970s, in searching for what makes streets liveable (Appleyard, 1981) or great (Jacobs, 1961), scholars have concluded that this depends on the intensity and plurality of pedestrian life (Strauskis \& Eckardt, 2011). It has been argued that there is, in fact, a strong link between the movement of pedestrians and the creation of place (Cresswell, 2004) as a culturally (Amin, 2008; Massey, 2005) and emotionally (Thrift, 2004) impregnated space. When walking, people communicate their social dispositions (Bourdieu, 1972; Casey, 1996), interact with the movement of others, and fully engage themselves in the environment (Macauley, 2000). In the 1990s, Michel de Certeau had already underlined the fact that it is the movement of pedestrians that truly shapes urban space: "The networks of these moving, intersecting writings compose a manifold story that has neither author nor spectator [...] They weave places together" (Certeau, 1984, p. 97).

Recent studies investigating the factors that influence pedestrian life within public spaces have examined the movement of pedestrians not only in terms of trajectories or social relationships, but also in terms of senses (Hiss, 1990; Zardini, 2005), emotions (Kenny, 2014), ambiances (Thibaud \& Chelkoff, 1993), or memories (Rosenberg, 2012). Furthermore, a 
public place is seen not only as a functional or social space but also as a place offering pleasure and entertainment (Lavadinho \& Winkin, 2008). As for pedestrians themselves, they are increasingly considered to be powerful players within the urban transport system (Amar \& Michaud, 2009). Walking is both a subject of research (Lee \& Watson, 1993) and a resourceful method for the investigation of city life (Augoyard, 1979; Pink, 2010). From the $19^{\text {th }}$ century's flaneur (Tester, 1994) to the modern urban nomad (Short, 2012), movement on foot seems to be the barometer of a city's life. More than a means of transportation, walking is today acknowledged as a central act of inhabiting and defining the city (Anderson, 2004; Groth \& Corijn, 2005).

Despite the fact that public services develop progressively through the knowledge, accumulated over years, of design materials and techniques for constructing public space, walking itself as a human technique (Mauss, 1960, p. 363) - the story of which goes back to the origins of humanity (Amato, 2004; Ingold \& Vergunst, 2008; Nicholson, 2010) - and social behaviour have not yet been explored by Athens' city planners. I argue that observing public life in a street context that has escaped the dominant model of public spaces that is used in the tourist zones can make a significant contribution to the discussion of ways of ensuring the vitality of public space.

\section{In search of animating public life: planners' visions and policies post-1970s in Athens}

Since the boom in the tourist industry in Greece in the 1960s (EIU, 1990, p. 49), the historical centre of Athens has based its tourist offer on the numerous archaeological sites embracing Acropolis Hill (Romanos, 1998). However, until the 1970s, aside from some central squares and paved pathways leading to the Parthenon temple, public space in the Greek capital did not engender much creativity or concern from the public authorities ${ }^{5}$. Planning departments and technical services ${ }^{6}$ within public authorities at that time were still staffed by civil engineers and technicians, whose main concern was to address the expansion of car traffic in the streets ${ }^{7}$ and the financial cost of the maintenance of public spaces. By the mid-1970s, a new generation of architects and planners occupied significant posts in the public sector ${ }^{8}$, and discussions on the quality of public space and new design methods and materials appeared on the technical services' agendas for the first time (Remoundou-Triantafylli, 2001). The project for Plaka's pedestrian precinct (prohibiting the use of cars within a thirty-five hectare area from the foot of the Acropolis), completed in the 1980s, reflects the decision by the authorities to drastically interfere in the landscape and land use of public spaces by investing massively in pedestrianisation projects (Zivas, 1983). It was shown that pedestrianisation zones had a significant positive impact on the retail profits of neighbouring stores (Mpetoura, Loukissas \& Oikonomou, 1997). Many of these pedestrian streets, created in the 1980s, are however still scattered across the city, and merely form a continuous network ${ }^{9}$ (Koulis, 2014). In the mid-1990s, with the prospect of the Olympic Games of 2004, the authorities decided to strengthen the role of Athens as a cultural tourist destination in Europe (Fola, 2011). In 1995, the government created the Society for the Unification of Archaeological Sites of Athens, which took responsibility for completing the colossal project of unifying and valorising monuments and archaeological sites (Figure 5) within an attractive walkable network of public spaces (Papageorgiou, 2000). 
Figure 5: Areas of intervention and emblematic projects of the Society for the Unification of Archaeological Sites of Athens

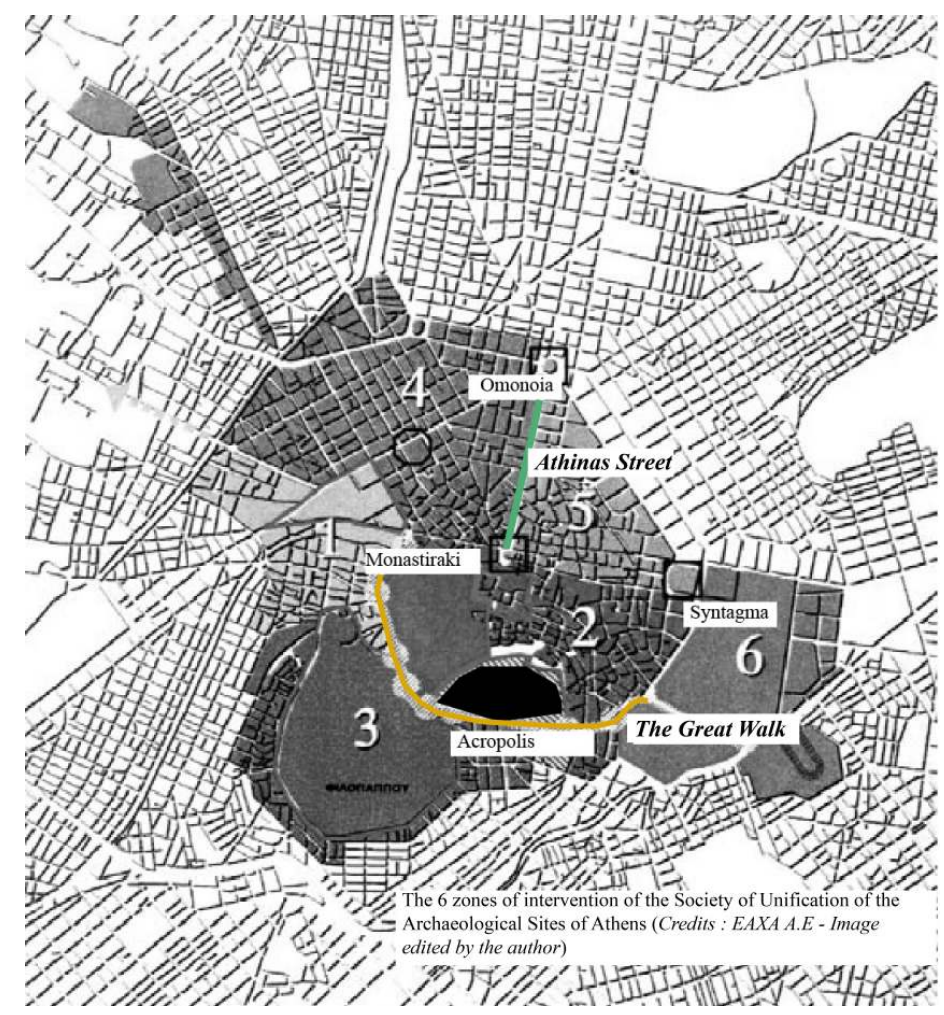

SOURCE AND COPYRIGHT: () DIMITRA KANELLOPOULOU.

The core of the project, a three-kilometre promenade passing along the former peripheral road of Acropolis Hill and linking the ancient cemetery of Kerameikos with the Temple of Olympian Zeus, experienced immediate success. The project's impact was also significant at a symbolic level. It introduced a new era of planning procedures and aesthetics and familiarised Athenians with new imagery of the social life of public spaces that was based exclusively on leisure activities. However, less quantifiable questions about how and when pedestrian life creates successful places were pushed to the margins.

\section{Athinas Street: where the screwdriver has conquered coffee}

Bisecting the isosceles triangle of the Kleanthes-Schaubert city plan ${ }^{10}$, Athinas Street has been at the heart of the commercial and public life of the city since the early years of its creation. Designed as a promenade avenue, conveying the principles of neoclassical urbanism (Bastea, 1994), the street's great width initially concerned Athenians, who considered this new urban landscape to be rather peculiar next to the tortuous paths of the Ottoman fabric (Kairofyllas, 2001, p. 26). By the mid-1850s, grocery stores had begun to display their goods on the pavements, offering a variety of products that left nothing to envy from European stores and providing a sense of luxury in the newly created capital. When, in the late 1890s, the traditional bazaar in the ancient Agora burnt down, the new central food market was created on the street, just across from the town hall, and Athinas Street experienced a significant boom (Micheli, 1997). Athinas Street was the 
passageway and the meeting point for travellers arriving in the capital from northern Greece or from the port of Piraeus (Mpiris, 1966, 1999), and it was the place where merchants from the countryside sold novelties or home-made products. By the beginning of the $20^{\text {th }}$ century, the markets of Athinas Street catered for every taste and wallet. The already stimulating life experienced a new boom with the extension of the railway in 1896 from Monastiraki Square to Omonoia Square (Nathenas, Kourmpelis, Vlastos et al., 2006). The industrial warehousing zone in the eastern section of the city attracted new manufacturing and construction workers searching for accommodation in the neighbourhoods of Kerameikos and Psirri and spending their free time in Athinas Street (Sitaras, 2011). Gradually, blacksmiths, woodworkers, and leather workers occupied the ground floor stores in Athinas Street next to toffee makers, bleachers and barbers' shops. The street's regulars were also differentiated: civil servants, soldiers and bankers, encountered choristers, embossers and beggars (Sitaras, 2011).

For several decades, Athinas Street was where Athenian public life converged (Mpiris, 1966, 1999). Street life managed to prosper at the ground floor level, below arcades, next to two traffic lanes and among parked motorcycles, supply trucks, newspaper stands, baskets (Figure 6) and displays of grains and herbs.

Figure 6: Unofficial use of pavement space

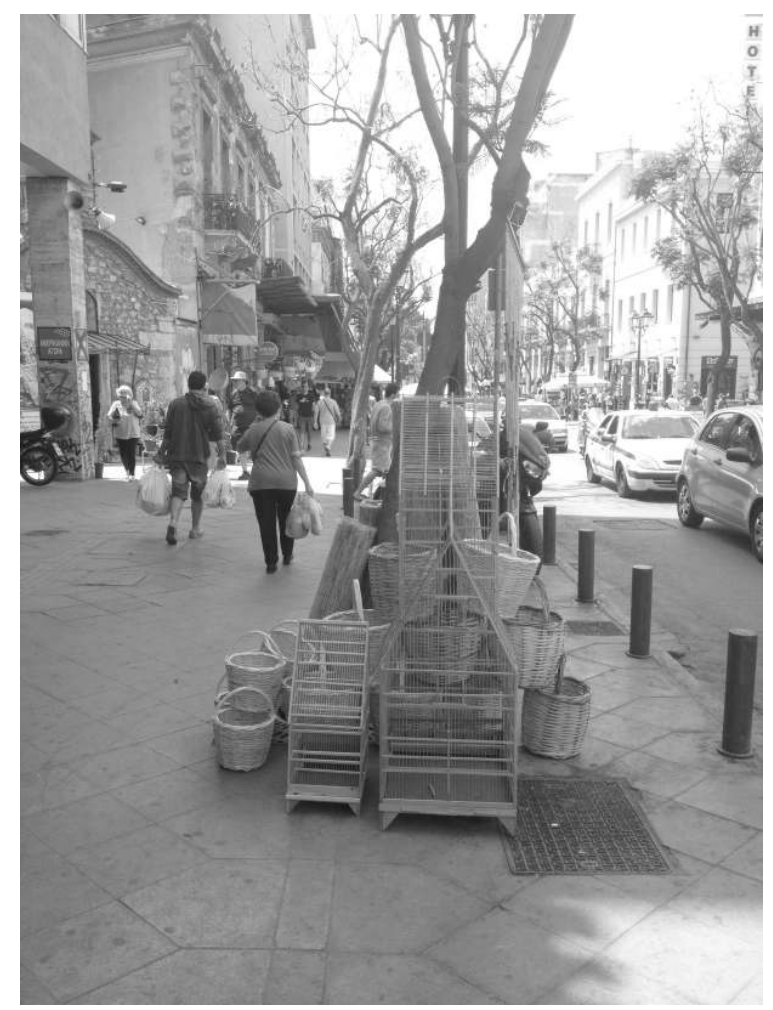

SOURCE AND COPYRIGHT: @ DIMITRA KANELLOPOULOU.

To a great extent, street life is based on the customer/shopkeeper relationship. This contact thrives in several ways; it could occur during a negotiation on the price of a product, when discussing the use of a blade machine, or simply in small talk about the morning's news in the capital. A dense crowd of pedestrians moves along the pavements ${ }^{11}$ and arrives from or turns into streets that are perpendicular to Athinas Street: Sofokleous, Evripidou, Sokratous, Aiolou, each of which specialise in different types of commerce. Street 
vendors from Africa sell their products, displaying them on white sheets on the pavement; booksellers, herbalists, cheese makers, youth hostels, florists, and glassware vendors compose the street image encountered by the walker's gaze (Figure 7).

Figure 7: Several types of commerce engage walkers' gaze

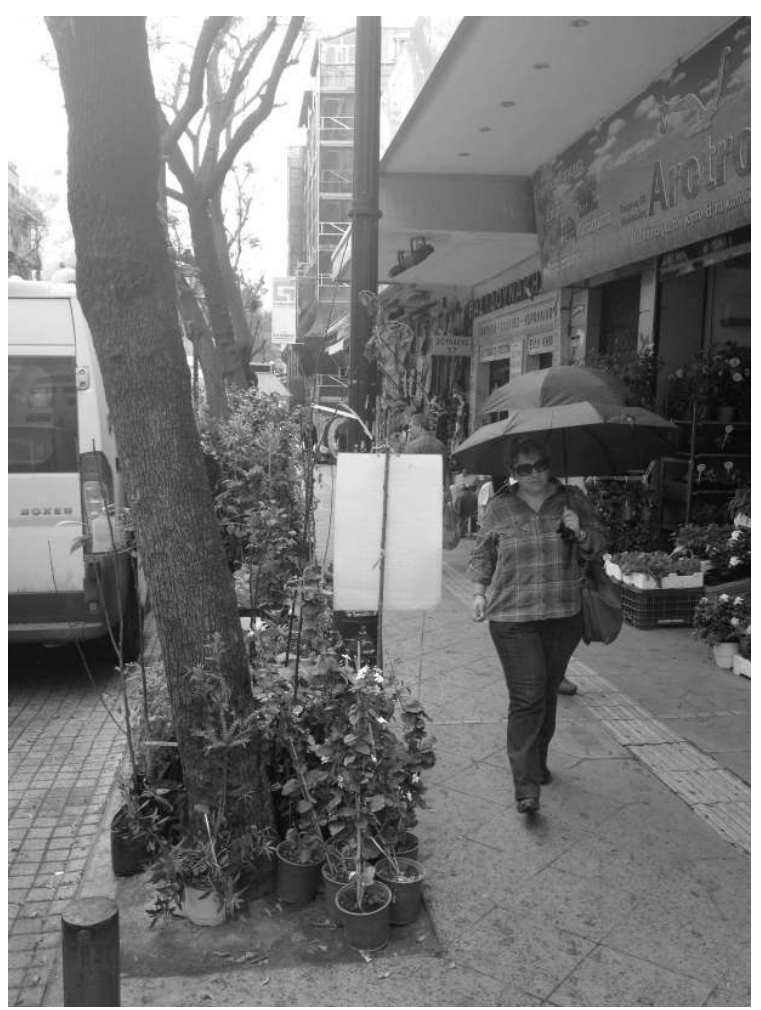

SOURCE AND COPYRIgHT: () DIMITRA KANELLOPOULOU.

\section{Walking among garlic braids and pliers: learning from the ground}

Some inherent characteristics concerning the morphology of the street have a strong impact on encoring pedestrian life to flourish. Athinas Street is a passageway but also a destination of pedestrian flow (thanks to its variety of commerce). The small scale of the urban blocks attracts walkers who, in this urban twisting weft, find a great range of options and routes from which to choose (Figure 8). 
Figure 8: Athinas Street (shown as a black line) within the historical centre of Athens

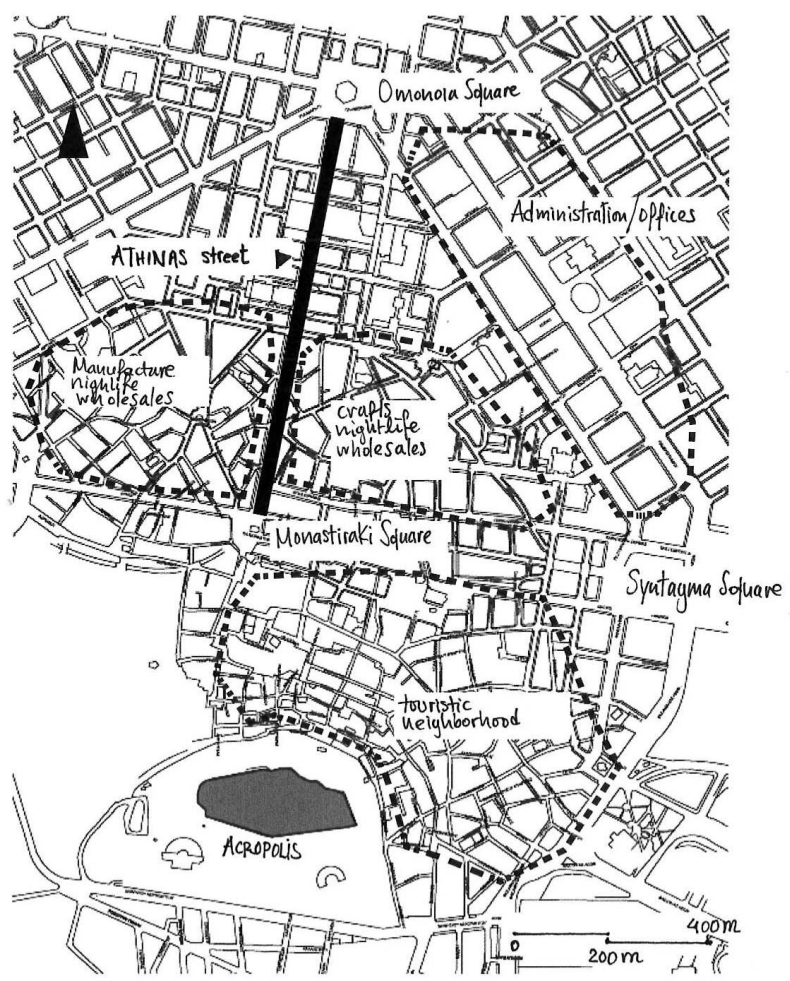

SOURCE AND COPYRIGHT: @ DIMITRA KANELLOPOULOU.

31 Arcades provide protection from the rain and sun (Figure 9), while during the hot sunny months, newspaper kiosks also offer also small shaded spots for the comfort of pedestrians. 
Figure 9: Arcades in Athinas Street

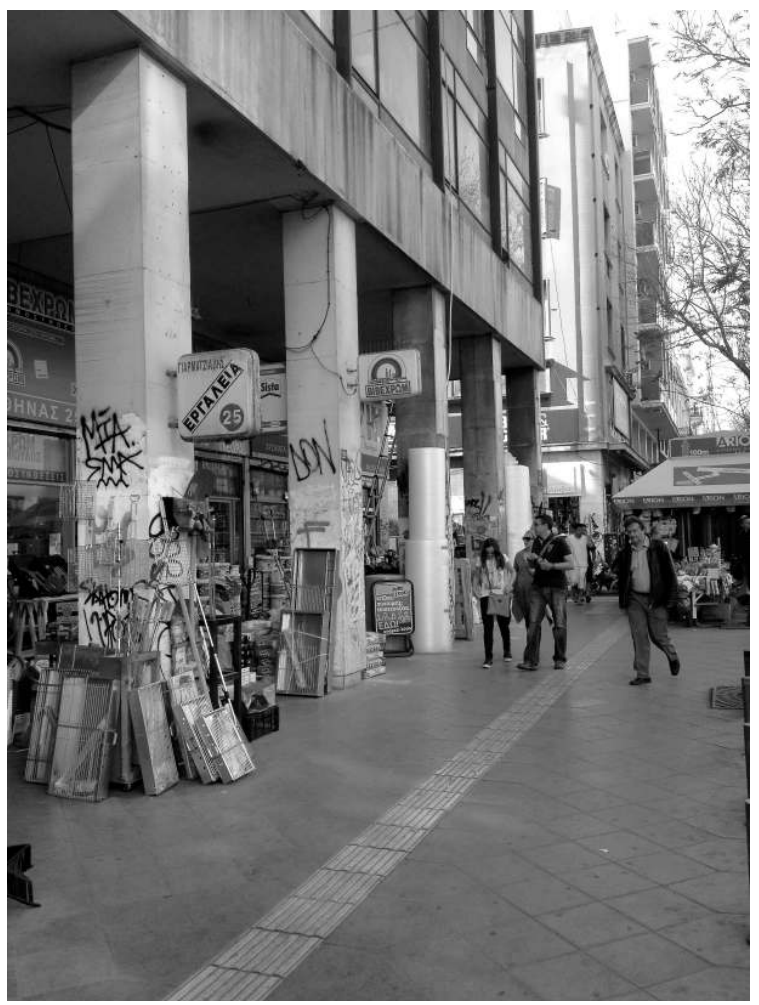

SOURCE AND COPYRIgHT: () DIMITRA KANELLOPOULOU.

Multiple crossroads, and small widenings or narrowings of the pavements, offer heterogeneous qualities of space that result in a variety of uses (Figure 10). Observations revealed five more 'qualities' of walking life that were present in Athinas Street. 


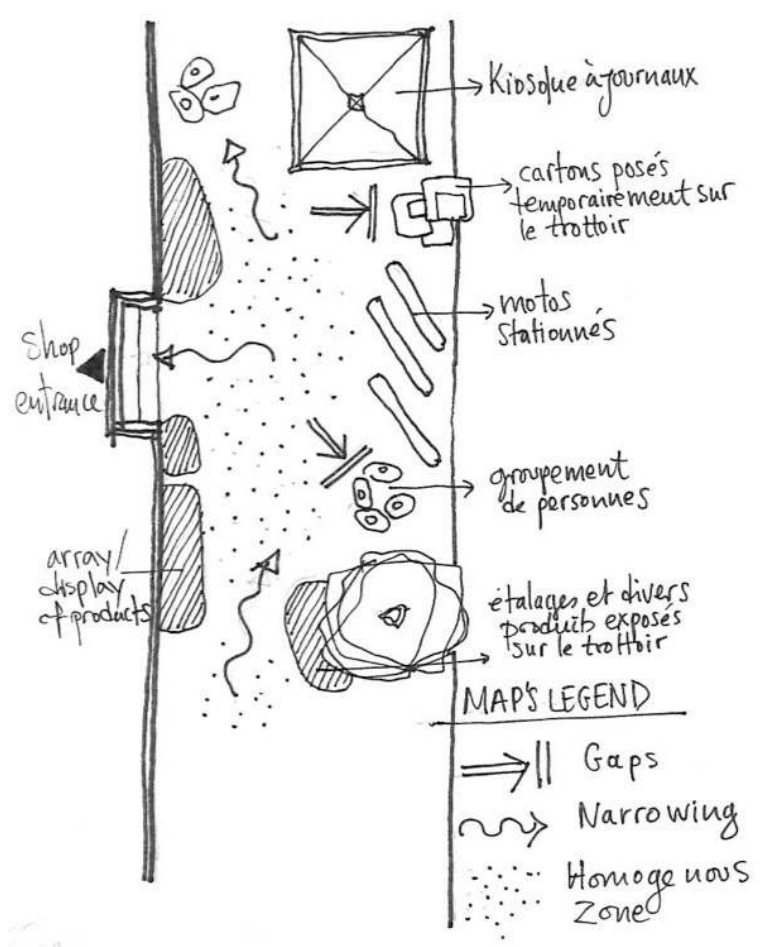

SOURCE AND COPYRIgHT: (C) DIMITRA KANELLOPOULOU.

1) Firstly, there is the complementary nature and interrelation of planned and unplanned uses, and porous boundaries between public and private space. Commerce depends to a great extent on the open-air display of products, and whilst this results in congestion of movement, it also provides great opportunities for interaction among pedestrians. Numerous street vendors, selling local fresh foods or cooking utensils in front of grocery stores, reinforce the porosity in the use of private and public space. Their presence at different spots on the pavements affects the linear trajectories of pedestrians (Figure11), and this has the result that walkers are more apt to stop to watch, talk, or buy something. 
Figure 11: Street vendor in Athinas Street

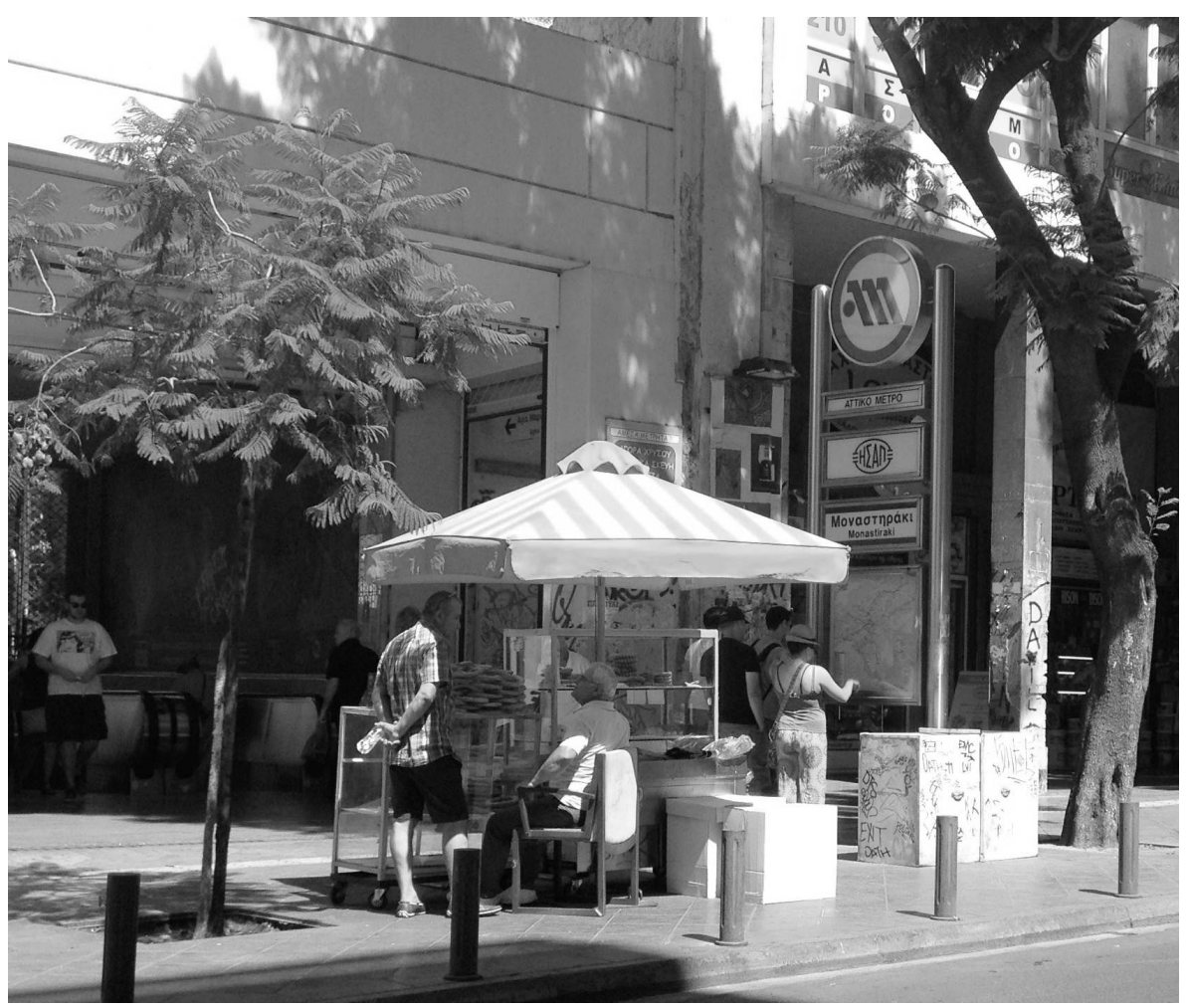

SOURCE AND COPYRIGHT: () DIMITRA KANELLOPOULOU.

On the outer space of the pavement, fixed or ephemeral elements (bollards, trees, benches and so on) create an unofficial protective barrier between the space where people walk and the road way. This visual enclosure of the pavement's space provides a feeling of protection for pedestrians and permits a less 'rushing' movement (Figure 12). 
Figure 12: Several elements creating a porous 'protective' barrier between the pavement and the road way

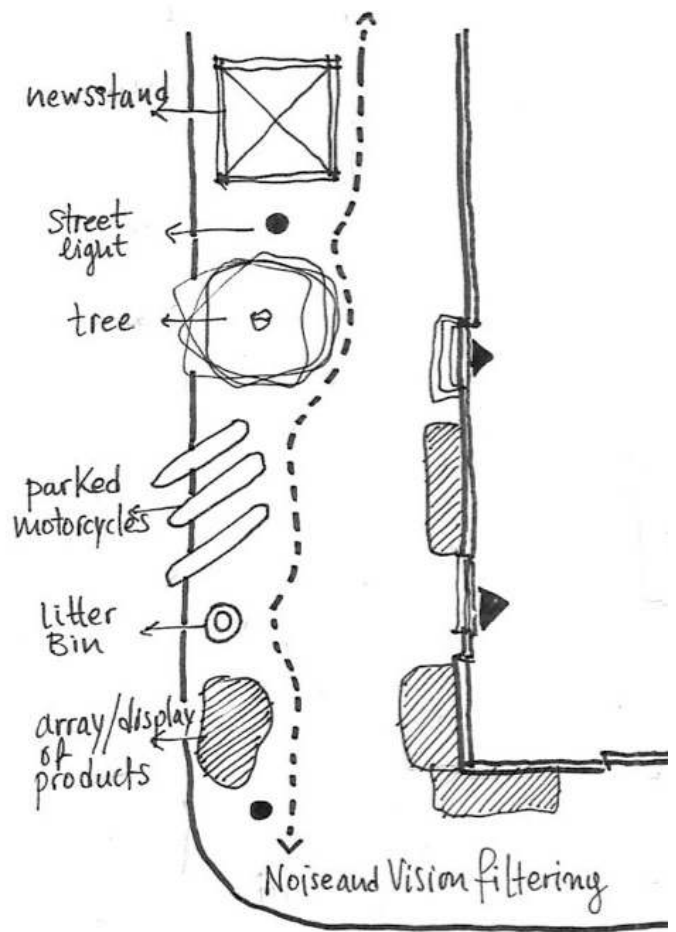

SOURCE AND COPYRIgHT: (C DIMITRA KANELLOPOULOU.

Traders often stand in front of their stores (Figure 13), talking among themselves or watching people moving on the pavements. 
Figure 13: A frequently observed activity: trader sitting in front of his/her store

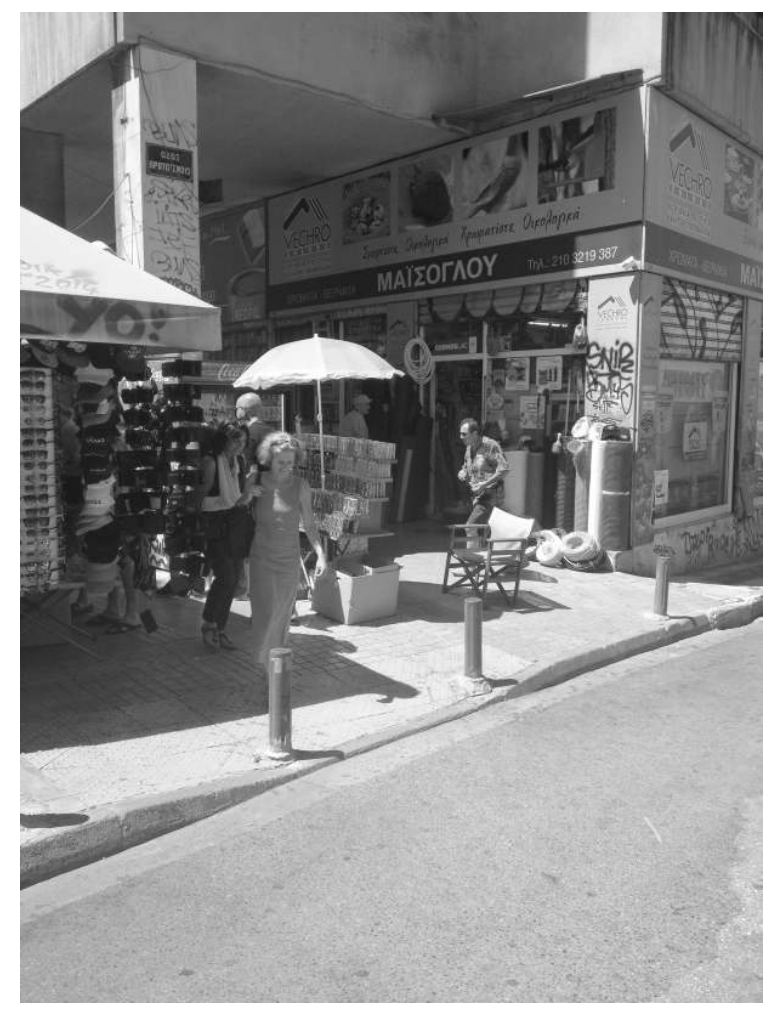

SOURCE AND COPYRIgHT: (C) DIMITRA KANELLOPOULOU.

The process of selling already begins in the public space, blurring the boundaries between the spaces for circulation and the spaces for trading. Thirteen out of the twenty people followed had a brief interaction with a trader. All the discussions occurred at the threshold of the stores, before the customer entered the shop or after having a detailed look at the displays outside.

2) Secondly, there is a plurality of rhythms of using pavements, which changes across users' profiles (vendors, passers-by, etc.) and over the course of the day. Apart from being a great way of spreading the intensity of use over time for a restricted space, this changes the visual environment of the street, whose regulars are not the same throughout the day.

Even if each itinerary appears on a map as a relatively linear trail, close to the ground this same movement is actually quite uneven and is composed of several micro-sequences. This 'wavy' movement of pedestrians is due to the morphology of the street, both at the level of the pavement and also on a larger scale. Athinas Street has many junctions with perpendicular streets where pedestrians tend to turn into or arrive from, and this results in intermittent movement, especially close to street corners. Secondly, many of the buildings have frontages that are not continuous, and this morphology guides pedestrians through a bending or winding trajectory (Figure 14). 
Figure 14: The presence of porticos affects the spatial organisation of activities on pavements

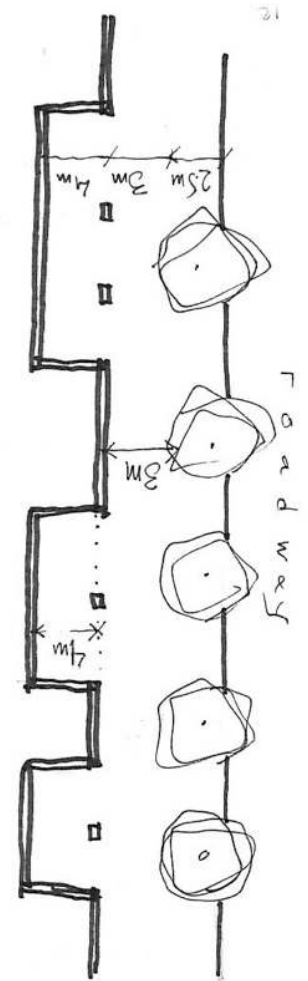

SOURCE AND COPYRIGHT: @ DIMITRA KANELLOPOULOU.

People generally move within an imaginary zone that is two metres in width in the middle of the pavement, and quite often they make slight detours in order to look more closely at display baskets and trays that are set out outside the shops (Figure 15). 
Figure 15: Most frequently observed patterns of walkers' trajectories

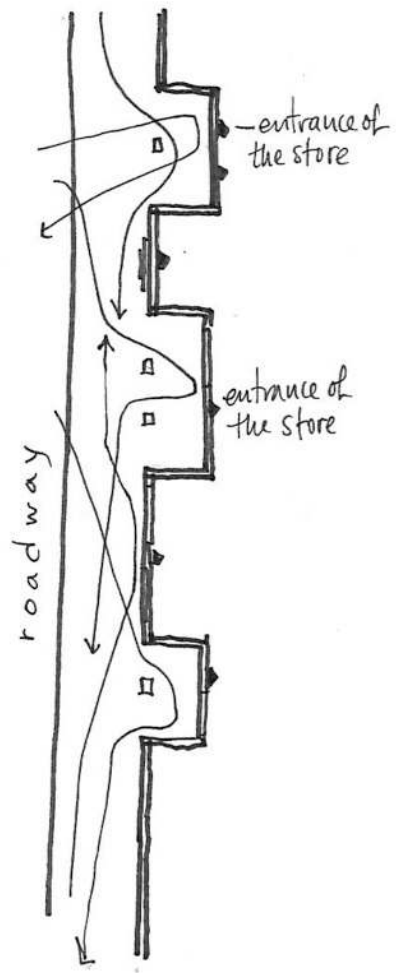

SOURCE AND COPYRIGHT: @ DIMITRA KANELLOPOULOU.

Pedestrians turn their gaze repeatedly towards shop windows and shop signs. The latter very often take the form of chalkboard easels that are set up at the outer edge of the pavement (Figure 16). 
Figure 16: Several kinds of signs, chalkboards and stands are set up at the outer side of the pavement

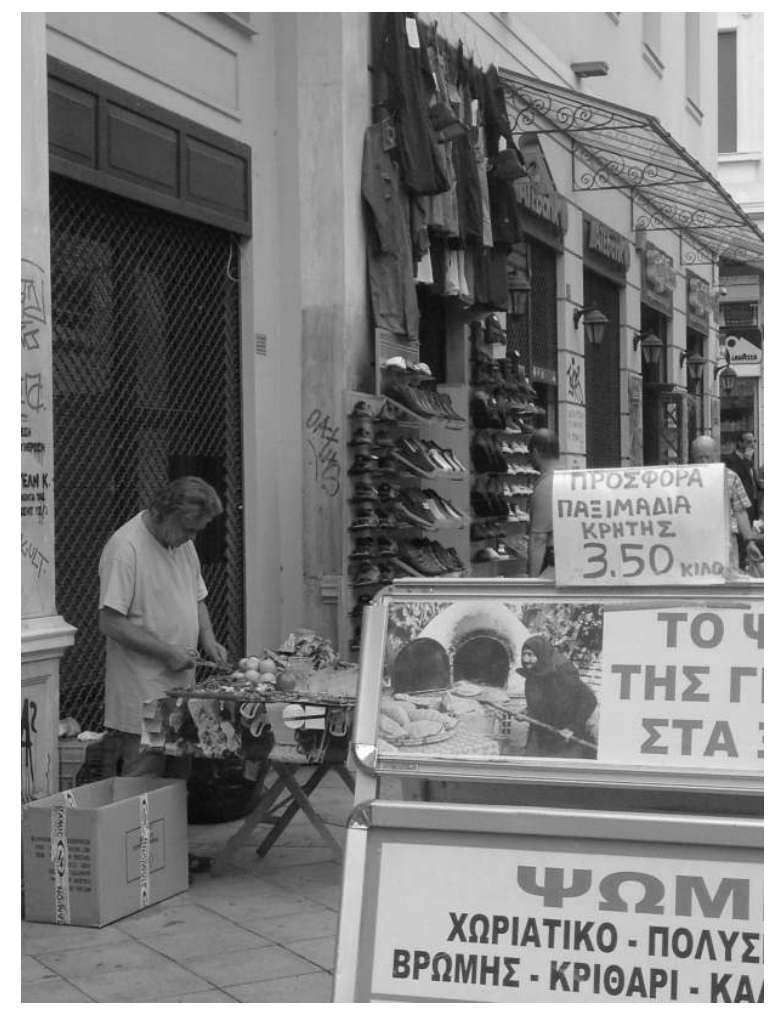

SOURCE AND COPYRIgHT: (C DIMITRA KANELLOPOULOU.

41 Whilst moving, pedestrians constantly turned their heads towards the shop façades, looking slightly downwards at the products displayed outside. This layout sometimes became an obstacle to the movement of pedestrians but sometimes, as the observations have shown, it creates the possibility of anchoring the pedestrians' gaze and route. The widespread phenomenon of displaying products outside the stores is, in itself, a factor that slows the walking pace and bends the trajectory of the pedestrians (Figure 17). 
Figure 17: Products are displayed outside the stores and around the columns of the porticos

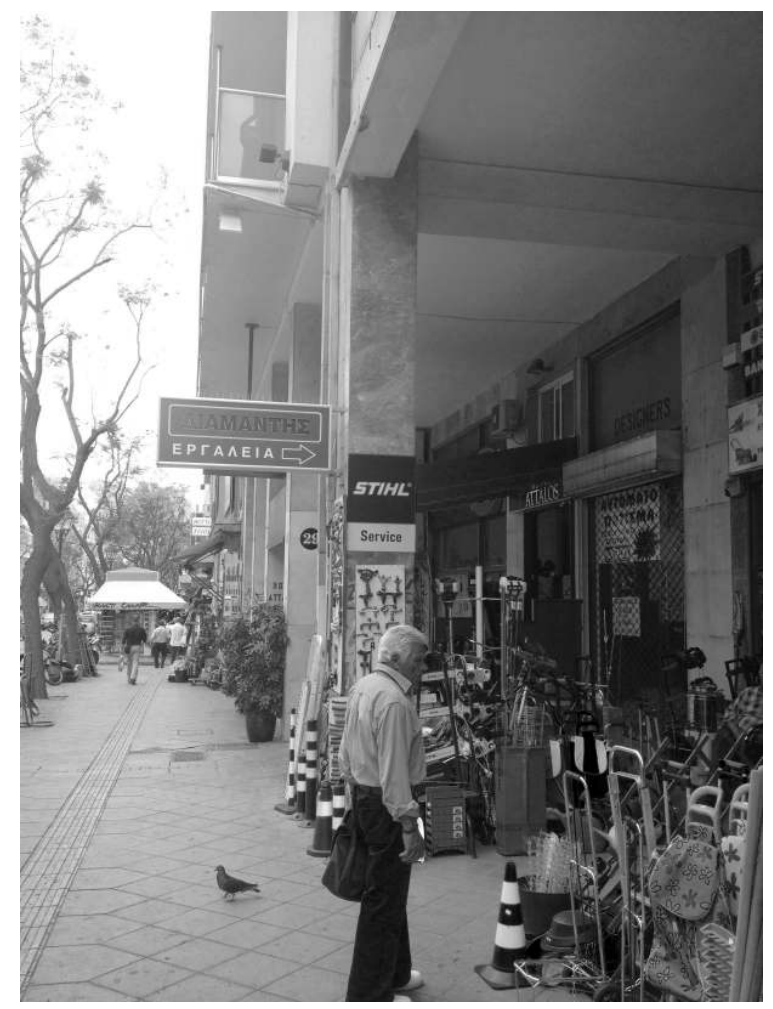

SOURCE AND COPYRIGHT: () DIMITRA KANELLOPOULOU.

3) A third characteristic is the heterogeneity of uses and close vicinity of different activities. The variety and types of trade influence the ways in which movement takes place on pavements. Many of the products on sale on the street need to be transported by vehicle. This results in numerous brief interactions between people moving along the pavements and those crossing the pavements from the drop-off areas for trucks or motorcycles (Figure 18). 
Figure 18: Conflict between walkers' movements is often caused by crossings perpendicular to the pavement (people arriving from the street and crossing directly the pavement towards a shop entrance)

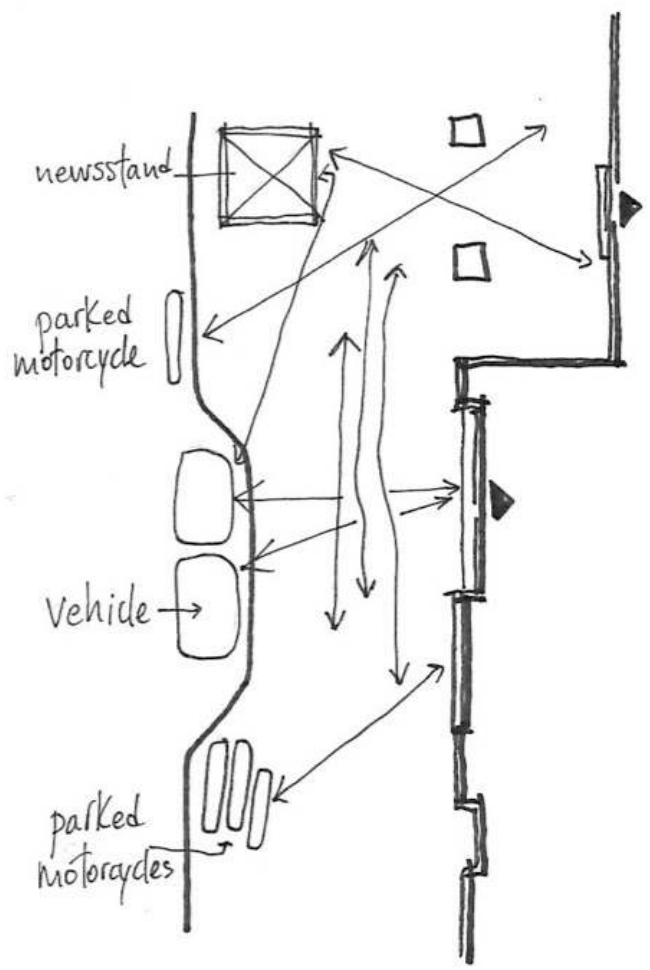

SOURCE AND COPYRIgHT: (C DIMITRA KANELLOPOULOU.

It has been already argued that pedestrians are ready to sacrifice their comfort in order to feed other psychological needs (Alfonzo, 2005). In three of the twenty observations, pedestrians chose not to take the fastest trajectory along the outside of the arcades but, rather, to take one running inside the arcade that presented greater visual attraction for them, even though the space was congested.

4) A certain margin of action and improvisation while using collective space can be considered to be a fourth important characteristic of walking activity in Athinas Street. In fact, a certain kind of visual control over anti-social behaviour is already exerted by street vendors. At the same time, the state seems very tolerant of small-scale traders who use the pavements as an extension of their shops. This sense of a 'loose' environment in terms of control and limits in relation to usage is also encouraged by a certain kind of 'self-regulation' in the use of the pavement. Merchants very often decide between themselves about where to hang things (interview with Th. 2012), how much space to occupy, and how to deal with a new street vendor. The continuous movement on the pavements is often interrupted by minor congestion due to customers going in and out of the shops, groups chatting in front of shop windows, or traders receiving deliveries for their stores. Despite the congestion, pedestrians manage to successfully regulate their movements in the vicinity of other walkers. Rules on the use of public space are not always followed either by pedestrians or by traders. However, social control, solidarity or even collusion are often present. Four of the pedestrians followed made remarks on motorcyclists riding on the pavements, two informed beggars of the arrival of the police, 
and three helped others when this became necessary (transportation of small objects, helping to settle disputes on the pavement).

5) A fifth characteristic of activities observed is the high degree of improvisation amongst walkers (passers-by) and traders (both street vendors and shopkeepers) and the appropriation of outside space. The pavements are occupied by static elements such as kiosks, bus stops, trees and lamp posts, whilst movable objects such as stands, motorcycles, barrels and baskets frequently oblige pedestrians to change their course (Figure 19).

Figure 19: Movable objects such as stands, motorcycles, barrels and baskets frequently oblige walkers to change their course

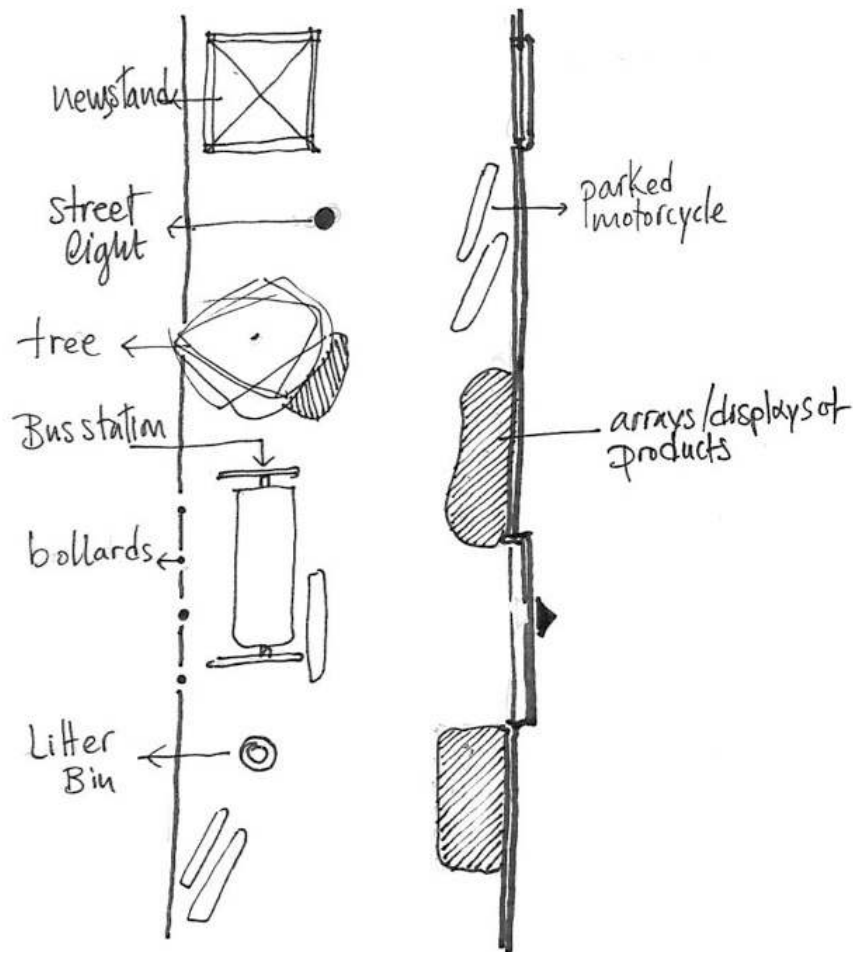

SOURCE AND COPYRIGHT: @ DIMITRA KANELLOPOULOU.

Although there is constant traffic on the two lanes of the road way, pedestrians perceive the street's open space as a possible surface for walking. They do not hesitate to cross the road or walk freely on it if the pavements are full or if their attention is suddenly attracted by something interesting on the other side of the street. No places have been designed for sitting in the street, with the exception of the small square across from Varvakeios market, but the pedestrians are highly creative when it comes to finding a place to take a rest. Benches at bus stops, bollards, parked motorcycles or electricity junction boxes installed in the street all become temporary resting areas or counters for putting down a bag (Figure 20). 
Figure 20: Elements of street furniture on the pavements are often used for purposes other than those for which they were initially designed

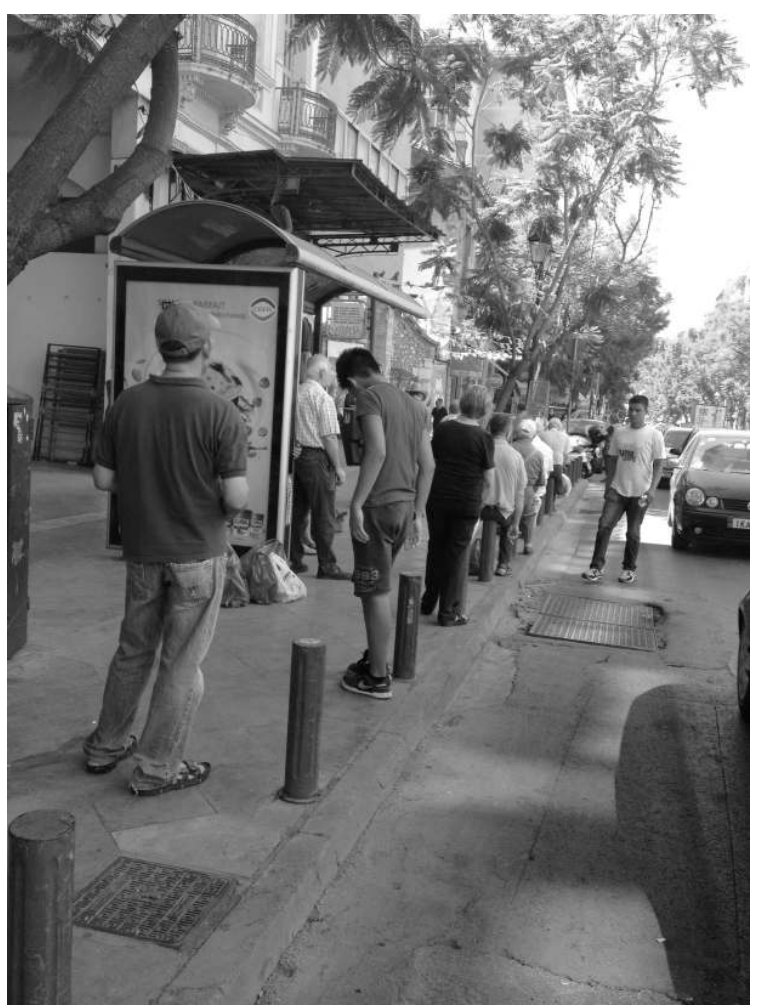

SOURCE AND COPYRIgHT: (C DIMITRA KANELLOPOULOU.

6) A sixth characteristic of pedestrian life is the presence of multiple stationary activities. Despite the lack of facilities designed for sitting or standing, gatherings of three of four people often occur next to kiosks, parked cars, bus stops and the columns of arcades. The display of products outside stores plays an important role in the disposition of stationary activities. Gatherings of people were also noticed around baskets or stands or street corners (Figure 21), and traders sitting next to their products started brief conversations with people passing by (Figure 22). 
Figure 21: Gatherings of people are also noticed around litter bins or newspaper stands, or at street corners

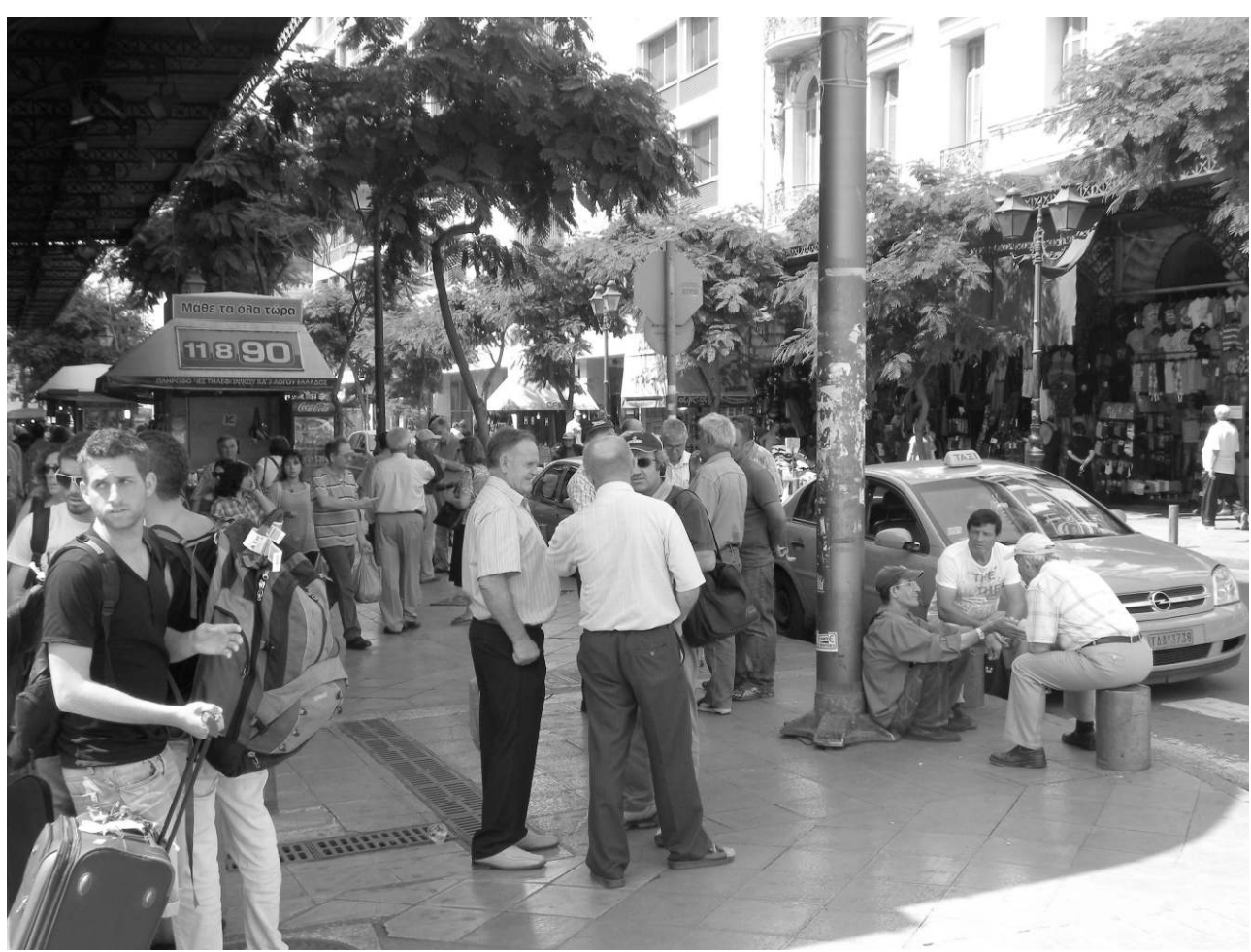

SOURCE AND COPYRIGHT: @ DIMITRA KANELLOPOULOU. 
Figure 22: Merchants often sit next to their products and start brief conversations with people passing by

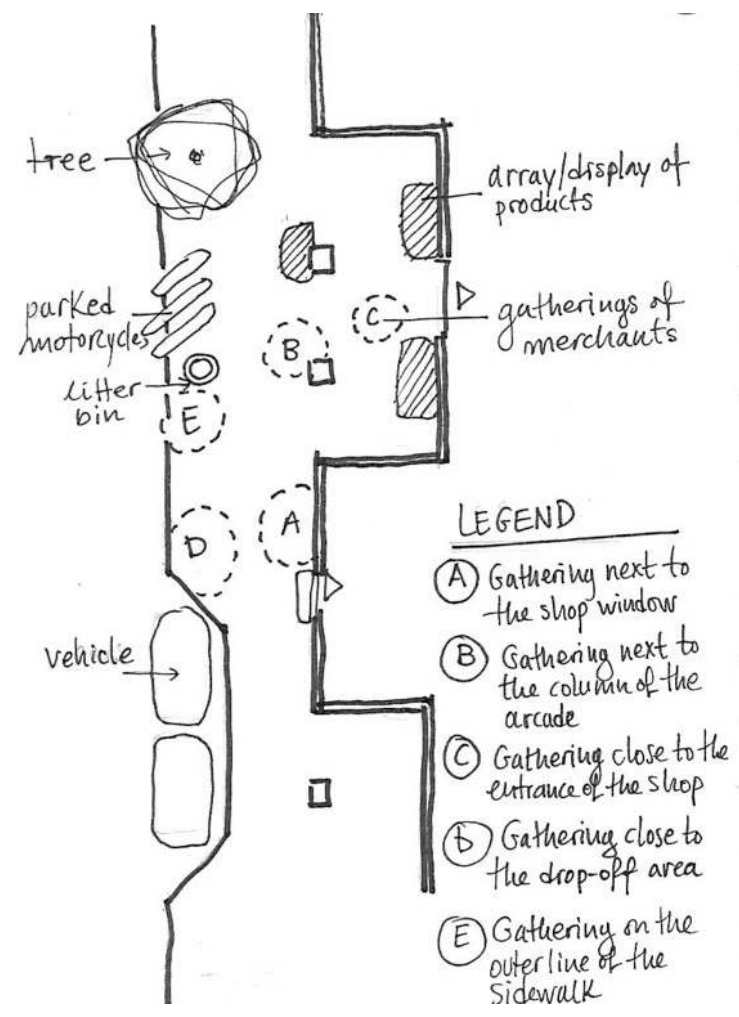

SOURCE AND COPYRIgHT: (C DIMITRA KANELLOPOULOU.

More marginal uses of the pavements, such as homeless people sleeping, begging or disputes occur close to abandoned buildings, the subway exits, or in places that are less visible from the crowded spots. Informal street vending is a widespread activity that generally occurs next to the fish market or on the outer edge of the pavements. In fact, the unstructured positioning of fixed elements on the pavements results in small uncluttered spaces between them that create protected mini-territories for people who are potentially looking to talk or to stand undistracted by the crowd moving next to them (Figure 23). 
Figure 23: Most observed zones of gatherings of pedestrians on pavements

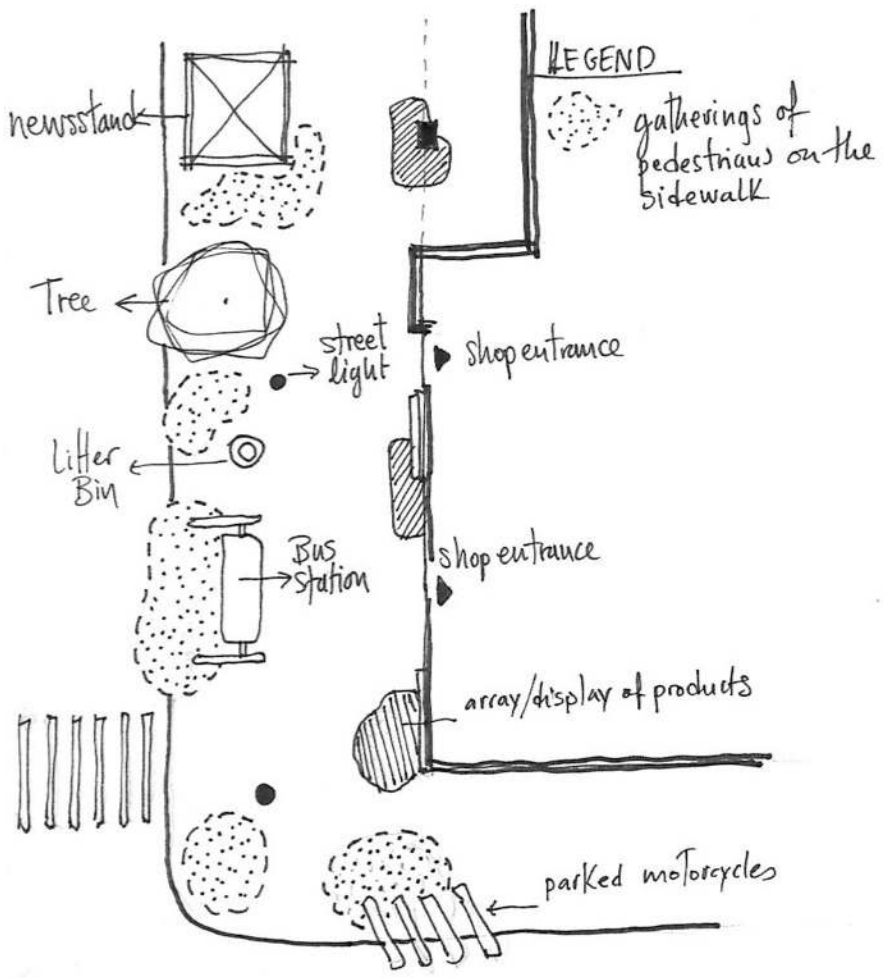

SOURCE AND COPYRIGHT: @ DIMITRA KANELLOPOULOU.

In contrast with pedestrians who are moving and whose contact with the environment is mainly a visual one with the shops, stationary pedestrians engage in more social activities, such as talking to each other, watching something, or waiting for someone. Sitting alone or standing alone were also frequently observed activities (Figure 24). 
Figure 24: Sitting alone or standing alone were also frequently observed activities

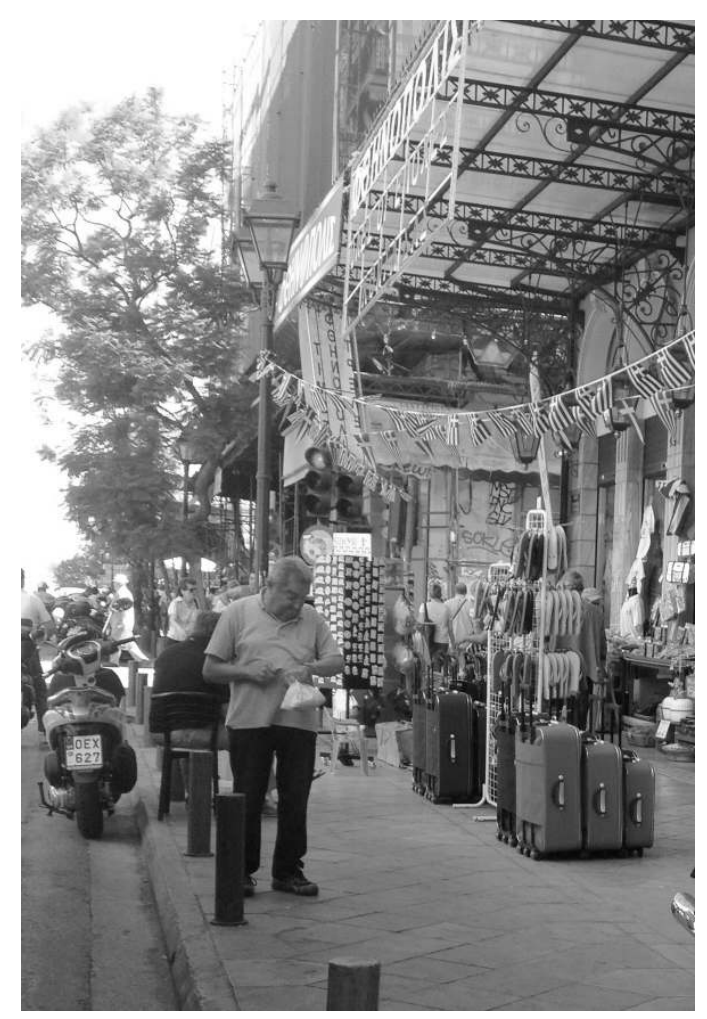

SOURCE AND COPYRIgHT: (C DIMITRA KANELLOPOULOU.

No artistic events that might have led to an intentional gathering of people took place in the street during the period of observation. However, small gatherings of strangers spontaneously took place around stands selling innovative kitchen utensils, or three-card trick dealers. Another stationary activity that was frequently observed took place around the news kiosks. Newspapers and magazines hang around the awning of the kiosk. People stop to read their front covers for several minutes without necessarily buying them. This co-presence of standing readers sometimes results in spontaneous discussions among them (Figure 25). 
Figure 25: Spontaneous assemblies of pedestrians around newspapers kiosks

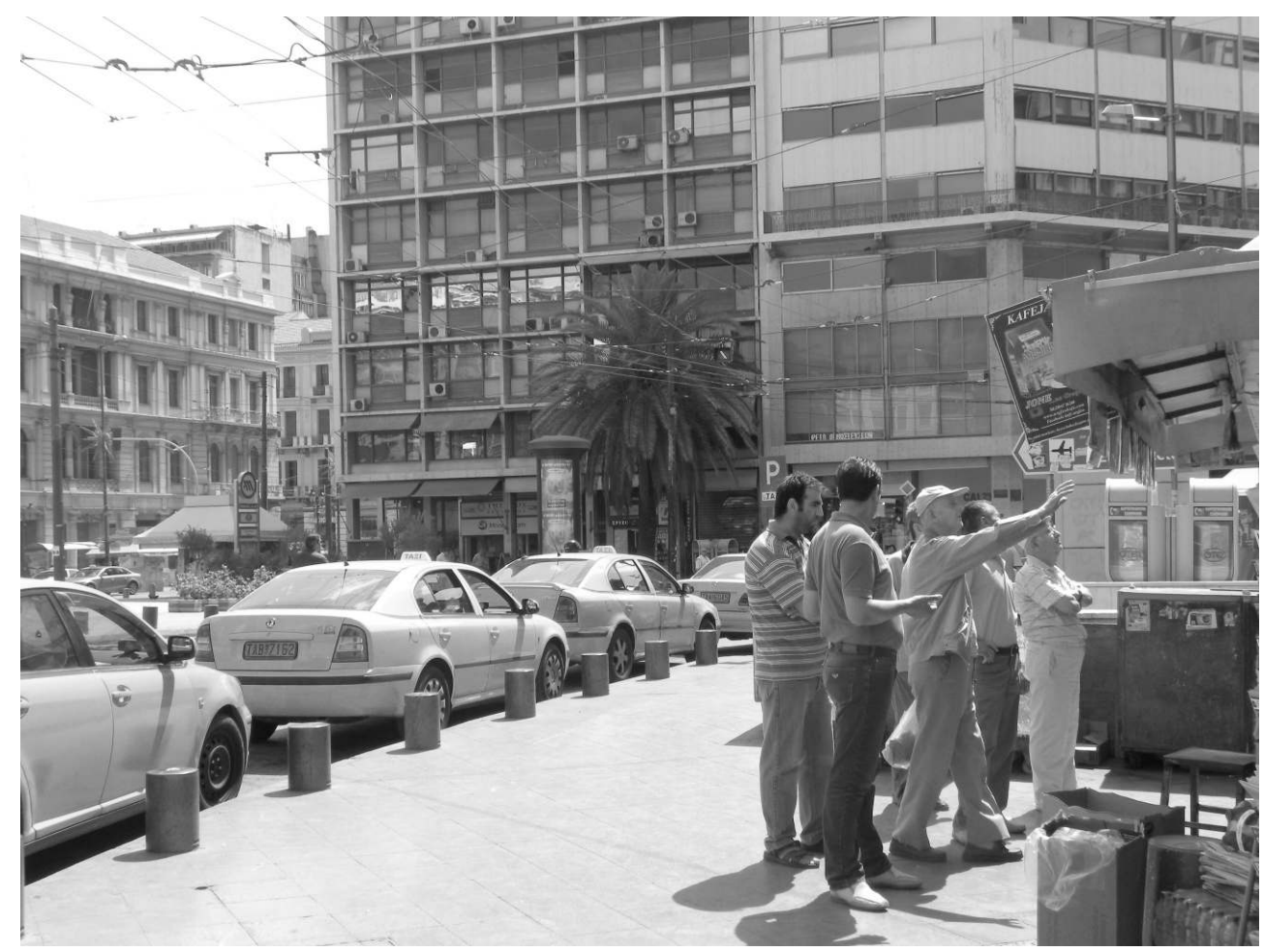

SOURCE AND COPYRIgHT: @ DIMITRA KANELLOPOULOU.

51 There are three zones where stationary activities are most observed: around kiosks or vendor stands, at crossroads, and at the outer zone of pavements. Activities of a shorter duration occur in the outer zone of the pavement and include brief discussions, purchases, or watching the arrival of products for the shops. Stationary activities never occurred in the zones of continual pedestrian circulation. However, street vendors attempted to 'hang out' next to zones where large numbers of people passed by. Finally, the variety of stationary activities depended not only on space attributes but also on daily and weekly rhythms. After seven o'clock in the evening most of the commercial activities had finished, and thus movements and activities diminished considerably (Figure 26). 
Figure 26: Movements and activities diminish considerably after 7 o'clock in the evening

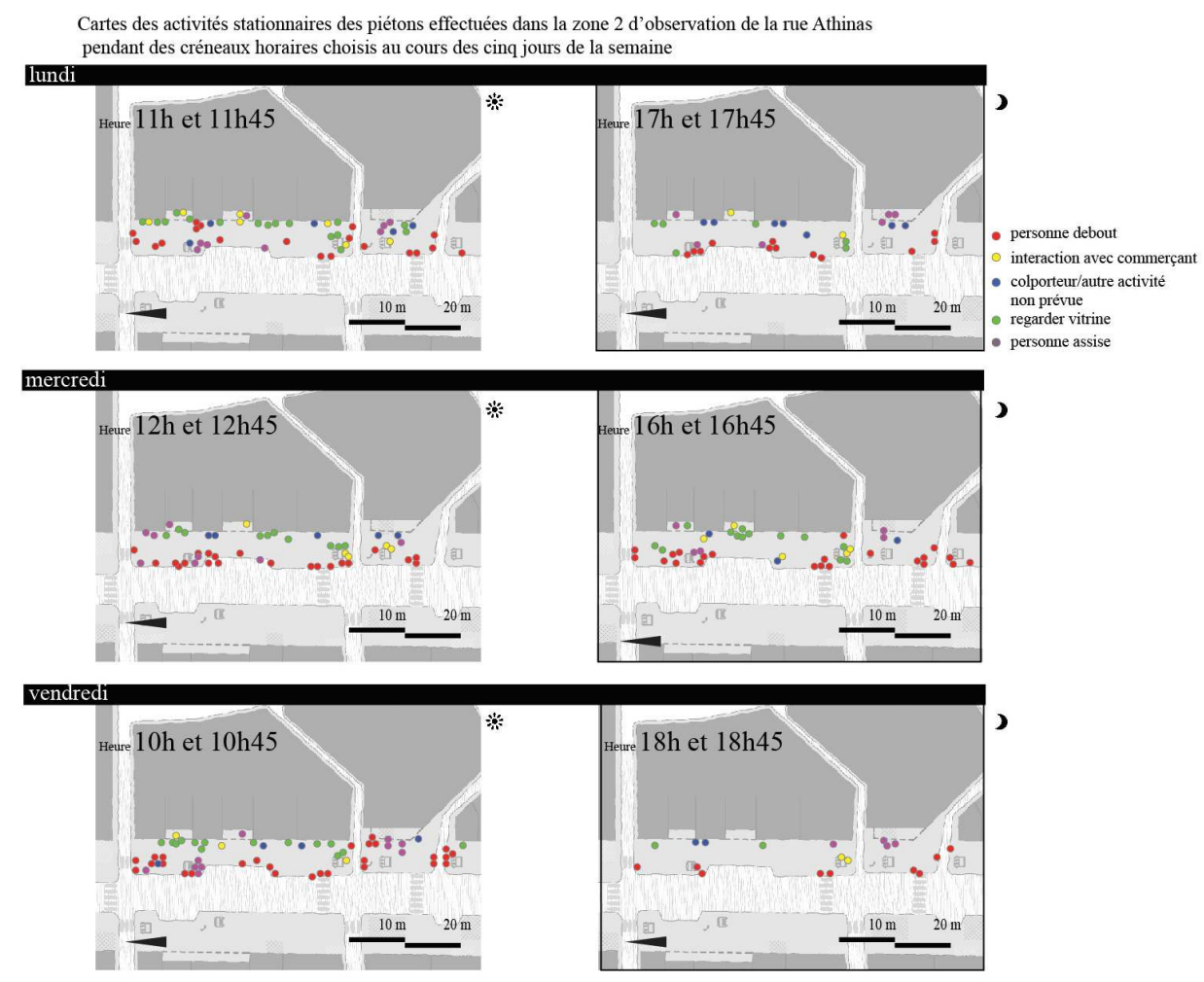

SOURCE AND COPYRIGHT: () DIMITRA KANELLOPOULOU.

\section{The main characteristics of pedestrian life observed in Athinas Street}

\begin{tabular}{|l|l|}
\hline 1 & Complementarity/interrelation \\
\hline 2 & Variety of duration and types of usage of public space during the day \\
\hline 3 & Heterogeneity and close vicinity of commercial activities and walkers' practices \\
\hline 4 & $\begin{array}{l}\text { Wide margins of informal vending deployed, lax police control, a certain freedom in the } \\
\text { appropriation of the pavements }\end{array}$ \\
\hline 5 & High improvisation while walking / plethora of stationary activities of a short duration \\
\hline
\end{tabular}

\section{Conclusions}

Observing walking in Athinas Street revealed that the enlivening of public space goes beyond planning intentions, street design objectives or management of events. The way in which people engage with place in a non-planned or intentional way, but also small actions of micro-mobility in space, give life to pavements and colour the general ambiance of the street. Liveability is created by the intensity in which movement and 
pauses are equally nourished by each other. Both pedestrian flows and stationary activities are highly dependent on the layout of the street but, more significantly, they occur thanks to the variety and the non-homogeneous dispersal of temporary or permanent uses of the pavements.

Observations brought up twelve potential factors in the enhancement of liveliness in Athinas Street. The vivid ambiance of the street is never linked to a trigger event, and it is not detected only in certain spaces. Rather, it arises within the routine uses of space, micro-situations of conflict or compliance, and the unintentional ways in which people share collective space.

1. A first pair of factors that give streets their animated ambiance is the heterogeneity of street level uses and pavement activities, and also, in respect of the latter, the close vicinity of these activities in space. The diversity of the architecture, shop window decoration and type of products offered contribute to attracting a varied public. In the case of Athinas Street, the vividness of street life depends on a certain freedom in the ways in which pavement space is appropriated both by passers-by and traders on pavements and inside the shops. The close vicinity of different types of shops (there are no firms or franchises) attracts a mixed clientele and fosters close encounters on pavements.

2. Variation in the duration of different uses of pavements also plays a prominent role in enhancing the liveability of the street. In fact, even in a very restricted zone of the pavement, multiple uses can follow on from each other, offering a changing spectacle throughout the day.

3. Street life is also highly reliant on the presence of synergistic activities in space. Vendors on pavements share public space and public furniture and operate thanks to the tolerance of shop owners and the municipal police. Street vendors selling cheap books or newspapers, and vendors of kitchen utensils, install their mobile stands in front of grocery stores. This 'cluster principle' (interview with A., 2012) also characterises the distribution of 'official' commerce inside shops along the street. Traders who were interviewed referred to Athinas Street as their street, and to other traders as an Athinas family (interview with M., 2012).

4. A great degree of tolerance characterises street life and offers people a sense of freedom in their acts in public. Poverty or begging are integral parts of street life and do not choke or seem to disturb other activities on pavements. A general sentiment that Athinas Street is a familiar place thrives also thanks to the improvisation of users and the continuous intensity of activities in the street throughout the daylight hours.

5. A high degree of porosity between the indoor private space and the outdoor public space also appears to have an impact on the vivid ambiance of the pavements.

6. Flexibility in the use of urban furniture also plays an important role in stimulating the liveable ambiance of the street. Benches at bus stops host small encounters between walkers, bollards are used for sitting while waiting for the bus, trees are temporarily transformed into clothing displays, and parked cars transformed into makeshift tables.

7. A further key factor that enhances public life is the existence of several unintentional 'barriers' and transition zones that divide the surface of the pavement into smaller insularities with distinct qualities that foster different stationary activities. The alignment of trees and bollards creates for example a loose barrier that gives pedestrians a certain amount of protection from the visual or acoustic annoyance of vehicles, whilst the columns of arcades create a transitional zone between shop windows and the continuous movement in the middle of the pavements.

8. The centrality of the street and the small-scale grain of the urban fabric ensure intense use of pavements throughout the day and offer numerous options for pedestrians to choose from or to change their trajectories. 
9. The sequential movement of pedestrians also adds to the vitality of street life. Far from being linear and direct, trajectories of walkers are affected by different elements that attract their attention, or force them to interrupt their movement. The multitude of walking sequences provides pedestrians with the opportunity to participate more actively in things that happen in the street, and to engage more easily with the environment. The arrangement of objects and activities on pavements, which appears complex at first glance, leads pedestrians to be more creative while using the pavements.

10. The exposure of each activity to the sight of everyone is also crucial for the numerous instances of successful neighbouring use of space: people standing, traders sitting outside their shops watching, street vendors and kiosk owners so close to each other that there is no space in the street that is unsupervised or underused.

11. It is rarely possible to say that one activity or social group dominates over another. Strollers, people rushing around, waiters crossing the street, motorcyclists searching for somewhere to park and workers testing a drill on a stand all cohabit in the daily life of the street. This seemingly chaotic urban scene allows the creation of optimum social experiences of public life, as others have already argued (Ellickson, 1996).

12. A general intense spectacle, both visual and olfactory, stimulates the senses of the walkers and leads them to a more engaged contact with their surroundings.

Besides producing public space themselves, locals and visitors to Athinas Street experience the city's history, locate emotional or heritage landmarks, and weave meanings both individually and collectively.

This study aimed to highlight a new approach in street analysis, in order for planners to take account of the plural dimensions of walking as an urban practice. In fact, a better understanding of why and how Athinas Street has become a liveable place will allow Greek decision-makers to deepen the debate on the role of public space in a context of economic and social crisis. Important investment in mega-projects needs to be questioned anew for its capability to be a pertinent tool for stimulating public life. Liveability can be defined differently by different groups of actors, but mostly it is felt in various ways by users of public space. A fresh look at the factors involved in the liveability of public space is needed for two reasons.

Firstly, because public space can be highly successful in terms of popularity and liveability with little intervention in terms of design. Secondly, because alternative ways of animating public space are necessary, I argue, to ensure variety in the image and function of public spaces, and thus their democratic character. Allowing opportunities for improvisation of actions seems to be a key element in animating public space. Assuring a great mixture of uses and user profiles at the basic level (rent control, avoidance of monopolies and dominance of franchises) seems to attract pedestrian flow and ensure a variety of socioeconomic profiles of people using the street. Providing public space with various opportunities and facilities for sitting and circulating can encourage people to stay in the public space for longer, and to interact.

Walking activity is the cornerstone of a lively public space in the case of Athinas Street, not only in terms of quantity (intensity of pedestrian flow) but mostly in terms of quality of activities (ways of walking, variety of practices, variety of walkers' profiles). By connecting outdoor and indoor activities at the ground floor level, walking is by itself a crucial factor in the liveliness of the street. The wide variety of routine walking activities and walkers' profiles ensure a highly changeable image of the same public space. Athinas Street offers opportunities for people to improvise their trajectory, change their mind, 
talk to a stranger, negotiate on a product's price, stand, watch, admire, be surprised, be moved and for that, it can be an interesting case study for further discussion on the role of walking in the everyday life of public spaces.

The author(s) would like to thank the Department of Planning of the municipality of Athens for access to documents. Thanks are also due to the three traders who agreed to be interviewed for this research (and whose anonymity is respected), the reviewers of this article and all the anonymous walkers giving life to Athinas Street.

\section{BIBLIOGRAPHY}

Alfonzo, Mariela A. 2005. To walk or not to walk? The hierarchy of walking needs. Environment and Behavior. vol 37, p. 808-836.

Amar, Georges \& Michaud, Veronique (eds.). 2009. La marche au cœur des mobilités. État des connaissances. Lyon : CERTU.

Amato, Joseph. 2004. On foot: a history of walking. New York: New York University.

Amin, Ash. 2008. Collective culture and urban public space. City: analysis of urban trends, culture, theory, policy, action. vol 12, $\mathrm{n}^{\circ} 1$, p. 5-24.

Anderson, Jon. 2004. Talking whilst walking: a geographical archaeology of knowledge. Area. vol $36, n^{\circ} 3$, p. $254-261$.

Appleyard, Donald. 1981. Liveable streets. Oakland: University of California Press.

Augoyard, Jean-François. 1979. Pas à pas : essai sur le cheminement quotidien en milieu urbain. Paris : Seuil.

Bastea, Eleni. 1994. Etching images on the street: planning and national aspirations. In: Z. Çelik, Zeynep, Favro, Diane \& Ingersoll, Richard (eds.). Streets: critical perspectives on public space. Oakland: University of California Press, p. 111-124.

Bourdieu, Pierre. 2000 [1972]. Esquisse d'une théorie de la pratique (précédée de trois études d'ethnologie kabyle). Paris : Seuil.

Casey, Edward S. 1996. How to get from space to place in a fairly short stretch of time: phenomenological prolegomena. In: Feld, Steven \& Basso, Keith (eds.). Senses of place. Santa Fe: School of American Research Press. p. 13-52.

de Certeau, Michel. 1984. The practice of everyday life. Trans. Stephen Rendall. Berkeley: University of California Press.

CETUR.1980. Rues et places piétonnes dans les quartiers traditionnels, conception et réalisation. Paris : Ministère de l'Environnement et du cadre de vie, Ministère des Transports.

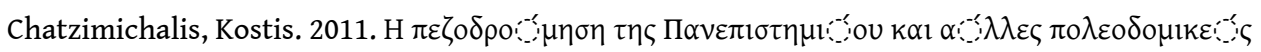

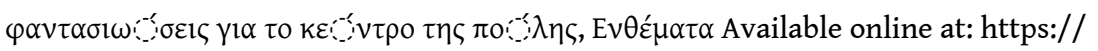
enthemata.wordpress.com/2011/05/15/hatzimihalis/ (consulted on March 9, 2016). 


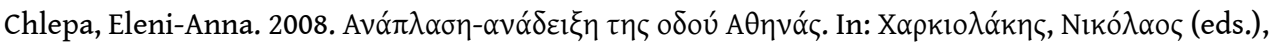

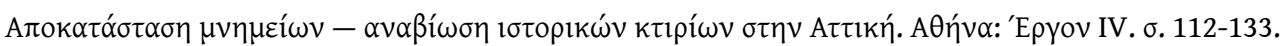
Cresswell, Tim. 2004. Place: a short introduction. Malden: Blackwell Pub.

EIU. 1990. Greece. International tourist reports. National Report, $n^{\circ} 4$. p. 45-62.

Ellen, Roy F. 1984. A Guide to General Conduct of Ethnographic Research. London: Academic Press.

Ellickson, Robert C. 1996. Controlling chronic misconduct in city spaces: of panhandlers, skid rows, and public space zoning. Yak Law Review. vol 105, p. 1165-1248.

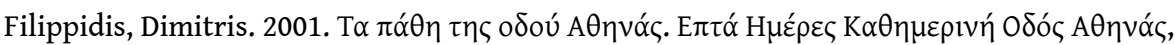
Kupıakń 17 Iouvíov. б. 29-31.

Fola, Maria. 2011. Athens City branding and the 2004 Olympic Games. In: Dinnie, Keith (ed.). City branding: theory and cases. London: Palgrave Macmillan. p. 37-47.

Gehl, Jan. 2011. Life between buildings using public space. Washington: Island Press.

Ghorra-Gobin, Cynthia. 2009. L'architecte, la façade et le piéton. Le Débat, n 155. p. 170-174.

Groth, Jacqueline \& Corijn, Eric. 2005. Reclaiming urbanity: indeterminate spaces, informal actors and urban agenda setting. Urban Studies. vol. 42, $\mathrm{n}^{\circ}$ 3, p. 503-526.

Habermas, Jürgen. 1988 [1962]. L'espace public. Archéologie de la publicité comme dimension constitutive de la société bourgeoise. Paris : Payot.

Harvey, David. 2008. The right to the city. New Left Review. vol 53. p. 23-40.

Hass-Klau, Carmen. 1993. The pedestrian and city traffic. London: John Wiley \& Sons Ltd.

Hiss, Tony. 1990. The experience of place. New York: Knopf.

Ingold, Tim, \& Vergunst, Jo L. 2008. Ways of walking: ethnography and practice on foot. Aldershot, England: Ashgate.

Jacobs, Jane. 1961. The death and life of great American cities. New-York: Random House.

Joseph, Isaac. 1984. Le passant considérable. Essai sur la dispersion de l'espace public. Paris : Librarie des Méridiens.

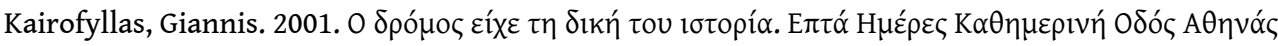
. Kupı๔kń 17 Iouvíov. б. 25-28.

Kanellopoulou, Dimitra. 2015. La marche plurielle : aménagements, pratiques et expériences des espaces publics au centre d'Athènes. Thèse de doctorat. Paris : Université Paris 1 Panthéon-Sorbonne.

Kenny, Nicolas. 2014. The Feel of the City: Experiences of Urban Transformation. Toronto: University of Toronto Press.

Lavadinho, Sonia \& Winkin, Yves. 2008. Enchantment engineering and pedestrian empowerment: the Geneva case. In: Ingold, Tim \& Vergunst, Jo L. (eds.). Ways of walking: ethnography and practice on foot. Aldershot and Burlington: Ashgate. p. 155-67.

Lawrence, A. Herzog. 2006. Return to the center: culture, public space, and city building in a global era. Austin: University of Texas Press.

Lee, John R. E. \& Watson, Rodney. 1993. Regards et habitudes des passants. Les Annales de la Recherche Urbaine. $\mathrm{n}^{\circ}$ 57-58. p. 100-109.

Lévy, Jean-Paul. 1987. Centres villes en mutation. Paris : Editions du Centre National de la Recherche Scientifique. 
Lofland, Lyn H. 1998. The public realm: exploring the city's quintessential social territory. Hawthorne: Aldine de Gruyter.

Macauley, David. 2000. Walking the city: An essay on peripatetic practices and politics. Capitalism Nature Socialism. vol. $11, \mathrm{n}^{\circ}$ 4, p. 3-43.

Mauss, Marcel. 1960. Sociologie et anthropologie. Paris : PUF.

Mehta, Vikas. 2009. Look closely and you'll see, listen carefully and you will hear: urban design and social interaction on streets. Journal of Urban Design. vol. 14, n 1. p. 29-64.

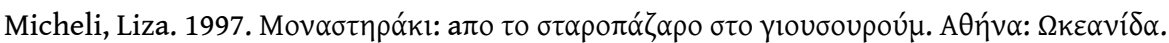

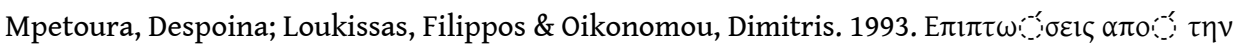
$\Pi \varepsilon \zeta о \delta \rho{ }_{-1}$

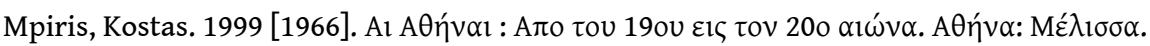

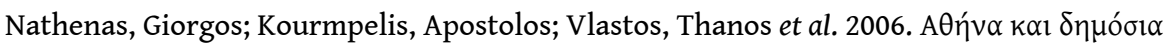

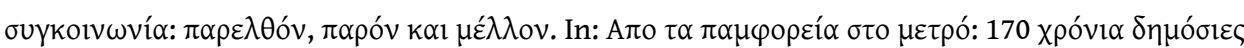

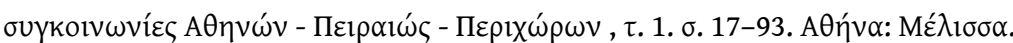

Oosterman, Jan. 1978. Welcome to the pleasure dome: play and entertainment in urban public space: the example of the sidewalk café. Built Environment. vol. 18, n 2. p. 155-164.

Papageorgiou, Loucia. 2000. The unification of archaeological sites of Athens: the birth of an archaeological park? Conservation and Management of Archaeological Sites. vol. 4, $\mathrm{n}^{\circ}$ 3. p. 176-184.

Pink, Sarah; Hubbard, Phil; O'Neill, Maggie \& Radley, Alan. 2010. Walking across disciplines: from ethnography to arts practice. Visual Studies. vol. $25, n^{\circ} 1$, p. 1-7.

Rapoport, Amos. 1970. The study of spatial quality. Journal of Aesthetic Education. vol. 4, $\mathrm{n}^{\circ}$ 4, $\mathrm{p}$. 81-96.

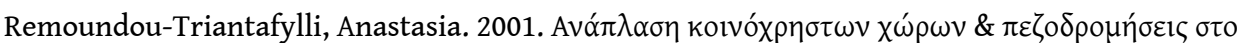

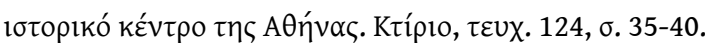

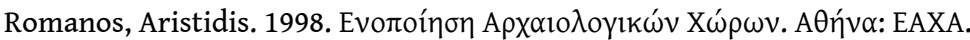

Rosenberg, Elisa. 2012. Walking in the city: memory and place. The Journal of Architecture. vol. 17, $\mathrm{n}^{\circ}$ 1. p. 131-149.

Sennett, Richard. 1990. The consciousness of the eye. New-York: Norton.

Shortell, Timothy \& Brown, Evrick (eds.). 2014. Walking in the European city: quotidian mobility and urban ethnography. Farnham, Surrey: Ashgate.

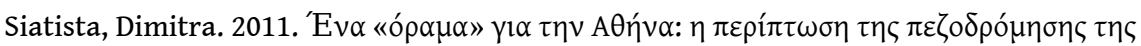

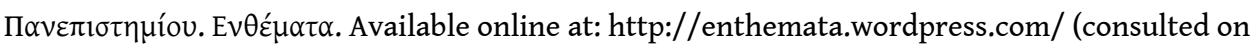
10 March 2016).

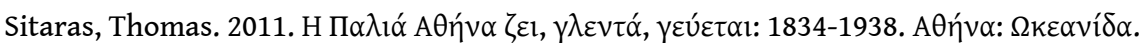

Solnit, Rebecca. 2000. Wanderlust: a history of walking. New-York: Viking.

Sorkin, Michael. 1992. Introduction: variations on a theme park. In: Sorkin, Michael (ed.). Variations on a theme park: the new American city and the end of public space. New York: Hill and Wang. p. XI-XV.

Stauskis, Gintaras \& Eckardt, Franck. 2011. Empowering public spaces as catalysers of social interactions in urban communities. Town Planning and Architecture. vol. 35, $n^{\circ}$ 2. p. 117-128. 
Tester, Keith. 1994. The flâneur. London: Routledge.

Thibaud, Jean-Paul \& Chelkoff, Grégoire. 1993. L'espace public, modes sensibles. Les annales de la Recherche Urbaine. $\mathrm{n}^{\circ}$ 57-58, p. 7-16.

Thibaud, Jean-Paul. 2002. L'horizon des ambiances urbaines. Communications. nº 7, p. 185-201.

Thrift, Nigel. 2004. Intensities of feeling: towards a spatial politics of affect. Geografiska Annaler, Special Issue: The Political Challenge of Relational Space. vol 86, $\mathrm{n}^{\circ} 1$, p. 57-58.

Whyte, William H. 1984. The gifted pedestrian. Ekistics. vol. 51, n 306, p. 224-230.

Wunderlich, Filipa-Matos. 2008. Walking and rhythmicity: sensing urban space. Journal of Urban Design. vol. 13, n 1, p. 125-139.

Zardini, Mirko (ed.). 2005. Sensations urbaines, une approche différente à l'urbanisme. Montréal and Baden: Centre Canadien d'Architecture and Lars Müller Publishers.

Zivas, Dimitrios. 1983. The saving of Plaka: Athens Part I. Monumentum. vol. 26, n 1, p. 3-21.

Zukin, Sharon. 2010. The naked city: the death and life of authentic urban places. New York: Oxford University Press.

\section{NOTES}

1. Jean-Paul Thibaud (2002) provides a thorough definition of the term, arguing that this is made up of the "whole set of rhythmical qualities that articulate our relationship with the environment and the others".

2. This was part of the fieldwork research for my thesis and was conducted over two summer periods between 2012 and 2014 .

3. Although the term 'pedestrian life' is often used among planners to demonstrate street life, in this study I prefer to refer to 'walkers' rather than 'pedestrians', in order to highlight the common features of several profiles and activities in a larger group, that of walkers in public space.

4. During the investigatory observation, certain parts of the street appeared to have more intense pedestrian activity. I chose to focus on three zones, one next to the market, one next to the metro station, and one next to a busy crossroads.

5. Manos, Stefanos. Personal interview. 12 March 2014.

6. The municipality of Athens, which is responsible for several intiatives relating to public space at the local level, was divided at the time into several technical services departments related to the landscape of green spaces, street pavements, and maintenance.

7. This was the result of an absence of political will, after the war, to invest in the construction of a functional public transport network.

8. Touri, Vagia. Personal interview. 15 August 2014.

9. Koulis, Stratis, personal interview. 20 March 2014.

10. I am referring here to the triangular form of the city plan proposed by the architects Stamatios Kleanthis and Eduard Schaubert.

11. I have counted thirty pedestrians per minute passing through an imaginary gate and moving in one direction. The count took place on a Saturday morning. 


\section{ABSTRACTS}

Over the last three decades the centre of Athens has been the site of numerous pedestrianisation projects, transforming the image and function of Athenian public space within a four square kilometre zone around Acropolis Hill. Local authorities largely promote pedestrianisation as a means of boosting the cultural tourist profile of the Greek capital. Surrounded by streets that are replete with tourist and commercial activities, Athinas Street has been the focus of discussions on future pedestrianisation since 2009. In the context of a growing debate on the need of radical gestures in order to stimulate life in public space, the paper aims to stimulate discussion about the forms and triggers of animation of street life that do not depend on traditional planning or event management. By means of close observation of walkers' itineraries, the study seeks to reveal the ways in which street life flourishes within a blend of pedestrians' different types of presence in public associated with the permeable boundaries between private and public space usage. The author, who takes an urban planning and ethnographic perspective, aims to contribute to the current growing debate in Europe on the transformation of public space through the promotion of environments that promote walking. The article suggests that the enlivening of public space thrives in Athinas Street thanks to a heterogeneous walkscape characterised by a diversity of practices, trajectories and profiles of walkers, all of whom contribute to enlivening the place and creating a local identity.

Au cours des trois dernières décennies le centre d'Athènes a fait l'objet de nombreux projets de piétonisation. Ils sont la manifestation de l'évolution de l'image et des fonctions des espaces publics autour de la colline de l'Acropole. Les autorités locales ont favorisé au fil des ans l'outil de la piétonisation comme un moyen de renforcement du profil touristico-culturel de la capitale grecque. Entourée des rues exposées à une forte activité touristique et commerciale, la rue Athinas se trouve, depuis 2009, à l'épicentre d'un débat sur des futures piétonnisations. A l'encontre d'un discours dominant sur la nécessité d'un geste "fort " afin de stimuler la vie publique au centre d'Athènes, l'article a comme objectif d'alimenter la discussion autour des formes et de la mise en œuvre de la vie sociale dans l'espace public qui ne dépendent pas de l'aménagement ou de programmation évènementielle. En observant de près des itinéraires routiniers des marcheurs, dans la rue Athinas, l'étude cherche à révéler le processus à travers lequel la vie publique prend forme grâce aux diverses postures et manières d'être dans la rue associées aux limites perméables des activités. L'auteur, qui adopte une perspective de planification urbaine et d'enquête ethnographique, vise à contribuer au débat actuel en Europe portant sur la transformation des espaces publics métropolitains via la promotion de la marche à pied et des mobilités douces. La pluralité de la marche repose, dans le cas de la rue Athinas, sur une diversité de pratiques, de trajectoires et de profils de marcheurs qui contribuent tous à l'animation du lieu et à la fabrication d'une identité locale propre. 
INDEX

Keywords: walking, public space policies, Athens, pedestrianisation, pedestrians, street life Mots-clés: marcher, politiques d'aménagement, espace public, Athènes, piétonisations, piéton, rue

\section{AUTHOR}

\section{DIMITRA KANELLOPOULOU}

Dimitra Kanellopoulou is an architect/engineer (National Technical University of Athens) with a Master's degree in urban planning (Ecole Nationale des Ponts et Chaussées) and a PhD in human geography (Université Paris 1 Panthéon-Sorbonne). She currently teaches at the Ecole Nationale Supérieure d'Architecture Paris-Malaquais (ENSAPM). She is a member of the LIAT research laboratory and associate member of the UMR 8504 Géographie-cités. Her research interests include public space planning policies, pedestrian practices, and soft mobility issues. 